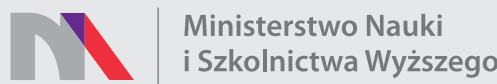

Digitalizacja archiwalnych numerów czasopisma naukowego Analecta Cracoviensia 1-24 (1969-1992) i ich publikacja w otwartym dostępie - zadanie finansowane w ramach umowy 672/P-DUN/2017 ze środków Ministra Nauki i Szkolnictwa Wyższego przeznaczonych na działalność upowszechniającą naukę

Ks. ADAM KUBIŚ

\title{
KOŚCIÓE JAKO SAKRAMENT W PRZEDPRZYGOTOWAWCZEJ DOKUMENTACJI II SOBORU WATYKAŃSKIEGO
}

\section{PROBLEMI FORMUEY EKLEZJOLOGICZNEJ.}

Zadanie nasze, którego w niniejszym studium pragniemy się podjąc, sprowadza się do poszukiwań w przedprzygotowawczej dokumentacji II Soboru Watykańskiego nie tyle definicji Kościoła w ścisłym znaczeniu tego słowa, co jakiejś - jednej wśród wielu możliwych — formuly eklezjologicznej. Możliwość ścisłej definicji przez podanie rodzaju i różnicy gatunkowej w odniesieniu do Kościoła - była bowiem i jest na dal kwestionowana przez wielu teologów. Misterium Kościoła, należąc do podstawowych misteriów chrześcijaństwa, pozostaje poza jakimkolwiek rodzajem i różnicą gatunkową. Ujęcie zatem $w$ tych kategoriach mysslenia przyniosłoby $\mathrm{w}$ konsekwencji tylko jego zubożenie a nawet zniekształcenie. Dlatego teolodzy zadowalają się z reguły tylko opisem istoty Kościoła, tzn. starają się uchwycić i przedstawić te wszystkie charakterystyczne elementy eklezjalne, które decydują o jego specyficznej naturze i misji, czyli podać formułę eklezjologiczną. Formuła eklezjologiczna stanowi więc tego rodzaju teologiczne określenie Kościoła, które w zwięzły sposób zbiera i wyraża wszystkie istotne dane Objawienia chrześcijańskiego na temat Kościala Chrystusowego. Tym samym formuła taka służy jego lepszemu poznaniu i głębszemu zrozumieniu ${ }^{1}$.

1 Por. K. Rahner, Geheimnis, LThK, 4 (1960) 596; H. Mühlen, Una Mystica Persona. Die Kirche als das Mysterium der Heilsgeschichtlichen Identität des Heiligen Geistes in Christus und den Christen: Eine Person in vielen Personen, München-Paderborn-Wien ${ }^{3} 1968,1.03 ; 1.22 ; 1.24-1.30 ; 1.42 ; 3.36,1 ; 3.37 ; 3.41 ; 3.43$; 3. $45 ; 5.17$; 7. $02 ; 7.60$; 8. $40 ; 9.47 ; 9.65 ; 13.01-13.16$; 13. 25; 13. 29; O. Semmelroth, Ekklesiologie. II. Wissenschaftstheoretische Überlegungen, LThK, 3 ('1959) 784. - O trudnościach i niemożliwości zdefiniowania Kościoła W. Beinert pisze następująco: „Geichsam die Gegenprobe für die aus alledem sich ergebende einzigar- 
Poszukiwanie właściwej formuly eklezjologicznej spawodowała reformacja XVI w. Wiadomo bowiem, że wcześniej bądź w ogóle nie było specjalnego traktatu o Kościele (do końca XIII w.), bądź też gdy się zjawił (z początkiem XIV w.), był ograniczony do zagadnień władzy: jej rodzajów, podziału, podmiotu, funkcjonowania itp. Natomiast reformatorzy - M. Luter (1483-1546), J. Kalwin (1509-1564), U. Zwingli (1484-1531) - dokonali po myśli J. Wiklefa († 1384) i J. Husa (13701415) podziału Kościola na widzialny i niewidzialny. Prawdziwym Kościołem Chrystusowym - według nich — jest riewidzialna wspólnota ludzi wierzących, która jednak nie utożsamia się ze swoją organizacją widzialną. Tym samym został zakwestionowany u samych podstaw cały ustrój widzialny Kościoła jako nie pochodzący od Chrystusa. Odcięcie i separacja Kościoła - Mistycznego Ciała Chrystusa od Kościoła-społeczności, będą odtąd stanowić zasadniczy przedmiot całej kontrowersji eklezjologicznej pomiędzy katolikami i protestantami ${ }^{2}$.

W odpowiedzi na to, ze strony katolickiej zostały sformułowane dwa różne typy odpowiedzi, mające za swych protagonistów $R$. Bellarmina (1542-1621) i J. A. Möhlera (1796-1838). Pierwsza z nich stwierdzając, że „nie istnieją dwa Kościoły, ale tylko jeden i że jest on zrzeszeniem ludzi, których zgromadza pod kierownictwem prawomocnych pasterzy, a zwłaszcza jedynego na ziemi zastępcy Chrystusa, biskupa rzymskiego, wyznawanie tej samej wiary chrześcijańskiej i wspólnota tych samych sakramentów", akcentowała dość jednostronnie zakwestionowaną instytucję Kościoła ${ }^{3}$. Druga z kolei, starała się dać bardziej wyważone określenie Kościoła uwzględniające oba jego aspekty ludzki i boski. W koncepcji tej „Kościół widzialny na ziemi jest pośród ludzi w ludzkim

tige Form und Gestalt der Kirche Christi liefert die Theologiegeschichte, insofern es ihr unmöglich war, die Struktur der Kirche definierend zu kategorialisieren. Das erwies sich mit biblischen Bildern als unmöglich, sofern sie nicht in ihrer ganzen Vielfalt genommen wurden und auch dann noch ungenügend blieben: Die Kirche ist weder Leib allein noch Braut, weder Volk noch Tempel exklusiv, sondern alles zusammen. Das ging auch nicht mit politischen Modellen: die Kirche kann weder als Demokratie noch als Monarchie, weder als Hierarchie noch als Oligarchie adäquat beschreiben werden. Sie ist ein Unikat der Geschichte - die eine, heilige, katholische und apostolische Kirche Christi", Der sinn der Kirche, w: Mysterium Salutis, hrsg. J. Feiner - M. Löhrer, Bd IV/1: Das Heilsgeschehen in der Gemeinde, Einsiedeln-Zürich-Köln 1972, 199.

2 B. Gassmann, Ecclesia Reformata. Die Kirche in den reformierten Bekenntnisschriften (Okumenische Forschungen'), Freiburg-Basel-Wien 1968. - Por. A. Kubiś, Wprowadzenie do Lumen gentium - Konstytucji dogmatycznej o Kościele, w: Idee przewodnie soborowej Konstytucji o Kościele, Kraków 1971, 13.

3 R. Bellarmini, De controversiis christianae fidei, t. II, Ingolstadii 1601, 137. - . Por. W. Eydka, Bellarminowska definicja Kościoła $i$ jej wpływ na późniejsza teologię katolicka, „Roczniki teologiczno-kanoniczne”, 13 (1966, z. 2) 57-75. - Weześniejszy rozwój tej koncepcji Kościoła, od czasów Konstantyna Wielkiego, zob. $\mathrm{H}$. Fries, Wandel des Kirchenbildes und dogmengeschichtliche Entfaltung, w: Mysterium Salutis, Bd IV/1: Das Heilsgeschehen in der Gemeinde, Einsiedeln-ZürichKöln 1972, 235-249 (Die Kirche im Gefolge der konstantinischen Wende - Kirche als Imperium). 
kształcie stale i wiecznie odnawiającym się Synem Bożym, czyli trwa jącym Wcieleniem (andauernde Fleischwerdung). Choć składa się z ludzi nie jest on wyłącznie czymś ludzkim: jest boski i ludzki równocześnie, jednością obu tych różnych elementów... (Inaczej mówiąc) to, co ludzkiə w Kościele, ukazuje się zawsze jako organ i obwieszczenie tego, co boskie”. W Kościele i przez Kościól Chrystus kontynuuje widzialnie dzieło zbawienia wśród ludzi ${ }^{4}$.

I trzeba od razu dodać, że wszystko, co zostało napisane na temat formuły eklezjologicznej pomiędzy Soborem Trydenckim (1545-1563) i Vaticanum II (1962-1965) nawiązywało w miejszym lub większym stopniu do tych dwóch podstawowych rozwiązań. Jeżeli I Sobór Watykański (1869-1870), ogłaszając dogmatem wiary katolickiej prymat i nieomylność papieską, definitywnie sankcjonował jedną z naczelnych tez eklezjologii instytucjonalnej ${ }^{5}$, to encyklika Piusa XII (1939-1958) Mystici Corporis Christi" (1943) przyniosła oficjalne potwierdzenie przez zwyczajne nauczanie papieskie teandryczno-chrystologicznego nurtu w eklezjologii katolickiej ${ }^{6}$. Oczywiście każde z proponowanych rozwiązań ma swe plusy i minusy, większą lub mniejszą ilość zalet czy braków ${ }^{6 a}$.

Formuła eklezjologiczna, która stanowi przedmiot naszego szczególnego zainteresowania, stawia w pewnej mierze znak równości pomiędzy Kościołem i sakramentem, czyli posługuje się elementami składowymi sakramentu dla określenia rzeczywistości Kościoła. Innymi słowy, stosunek zachodzący pomiędzy sakramentalnym znakiem i zdziałaną, dzięki Chrystusowi, przezeń łaską spożytkowuje się w niej jako analogię do przedstawienia wzajemnych relacji zachodzących pomiędzy tym, co ludz-

4 J. A. Möhler, Symbolik oder Darstellung der dogmatischen Gegensätze der Katholiken und Protestanten nach ihren öfentlichen Bekenntnisschriften, Bd I, Köln 1960, 389. - Na występowanie tej samej koncepcji Kościoła już w okresie patrystycznym i scholastyce wskazywał S. Tyszkiewicz, Où en est chez nous la doctrine de la divino-humanité de l'Eglise, „Orientalia Christiana Periodica", 7 (1941) $371-375$.

5 Conc. (oecum. XX) Vaticanum I: Sessio IV, 18. Iul. 1870: Constitutio dogmatica I "Pastor aeternus" de Ecclesia Christi, DS 3050-3075.

6 Pius XII, Litt. encycl. „Mystici corporis”, 29. Iun. 1943, DS 3800-3822. Por. $A A S, 35$ (1943) $200 \mathrm{nn}$.

6 a ,So ist etwa in der Bellarminschen «Definition» zwar die irrtümliche Vorstellung einer ecclesia invisibilis ausgeschlossen; zugleich enthält diese "Definition» aber in sich den Keim eines naturalistischen Missverständnisses der Kirche, wie gezeigt. Bei Möhler auf der anderen Seite ist ein naturalistisches und deistisches Missverständnis der Kirche ausgeschlossen; das Bild von der "andauernden Fleischwerdung» des Sohnes Gottes aber ist offen für einen möglichen ekklesiologischen Monophysitismus und Mystizismus, wie erwänt. Sicherlich wird man sagen können, dass der Irrtum immer nur eine einseitige Utbertreibung bzw. "Verlängerung» der Wahrheit ist und dass in diesem Sinne keine wahre Aussage vor einem möglichen Missverständnis geschützt ist”, Mühlen, Una mystica persona, 1. 22. - Bliżej o chrystologiczno-eklezjologicznych błędach zob. F. Holböck, Das Mysterium der Kirche in dogmatischer Sicht, w: Mysterium Kirche in der Sicht der theologischen Disziplinen, Teil I, hrsg. von F. Holböck - Th. Sartory, Salzburg 1962, 234-239. 
kie i co boskie w Kościele: pomiędzy Kościołem-społecznością i Kościołem-wspólnotą łaski, stanowiących jedną złożoną rzeczywistość eklezjalną. Formuła ta swymi najgłębszymi korzeniami tkwi w chrystologicznej orientacji eklozjologicznej. Jak bowiem sam Chrystus jest prasakramentem ludzkiego zbawienia, ták i Kościół analogicznie może być nazwany sakramentem, ponieważ stanowi $\mathrm{w}$ powiązaniu $\mathrm{z}$ Nim instytucję zbawienia ${ }^{7}$.

To nazywanie Chrystusa i Kościoła sakramentem - należy tutaj od razu zaznaczyć - jest przede wszystkim rezultatem dogłębnie odczytanej chrystologii i eklozjologii, a nie akomodacją stosunkowo późno wypracowanego pojęcia sakramentu. Wiadomo bowiem, że zarówno w Chrystusie jak Kościele istnieją trzy zasadnicze komponenty, bez których nie sposób w pełni ich odczytać, zrozumieć i określić. Najpierw strona widzialno-cielesna: w Chrystusie ciało, a w Kościele cała zjawiskowa rzeczywistość. Następnie naturalna duchowa zasada życia: w Chrystusie ludzka dusza, czyniąca Jego Ciało żywym ludzkim ciałem, a w Kościele duchowo-intencjonalne związki, które różnych ludzi i ich dostrzegane działanie przekształcają w jedną ludzką społeczność. Wreszcie wcześniejszy od wymienionych składników współkształtujący je element boski: w Chrystusie druga Osoba Trójcy Swiętej, a w Kościele Duch Święty, będący duszą Kościoła, którego człowiek powinien mieć gdy staje się członkiem widzialnego Kościoła ${ }^{8}$. Chrystus zatem jest prawzorem wszelkiej sakramentalności. „Tutaj na ziemi Kościól jest tak sakramentem Jezusa Chrystusa - napisał H. de Lubac -- jak człowieczeństwo Jezusa Chrystusa jest dla nas sakramentem Boga" ${ }^{9}$. Sakramentalna wizja Kościoła radzi się na chrystologicznym gruncie i jako taka pozostaje z nim nierozerwalnie sprzężona.

' Mühlen, Una mystica persona, 11. 65. - Syntetyczne ujęcie całości tego problemu daje U. Valeske, Votum Ecclesiae, 1. Teil: Das Ringen um die Kirche in der neueren römisch-katholischen Theologie. Dargestellt auf dem Hintergrund der evangelischen und ökumenischen Parallel-Entwicklung, München 1962, zwłaszcza w 11. Kapitel zatytułowany "Göttliches" und "Menschliches" in der Kirche, 160-195. O zaletach i brakach ,sakramentalnego" spojrzenia na Kościół pisze z kolei O. Semmelroth, Um die Einheit des Kirchenbegriffes, w: Fragen der Theologie heute, hrsg. v. J. Feiner - J. Trütsch - F. Böckle, Einsiedeln-Zürich-Köln 1957, 326-327.

$\$$,In Wirklichkeit wird man, wie bei Christus selbst, so auch bei seiner Kirche drei Komponenten festhalten müssen, um sie ganz zu erkennen; das Sichtbar-Leibliche, bei Christus sein menschlicher Leib und bei der Kirche alles, was an Sichtbarem in ihr enthalten ist; dann das natürlich - geistige Lebensprinzip, bei Christus seine menschliche Seele, die den Leib zum lebendigen Menschenleib macht, bei der Kirche jene geistig - intentionale Wirklichkeit, die die vielen Menschen und alle sichtbaren Funktionen zur Einheit menschlicher Gesellschaft bringt; und schliesslich das dem Vorgenannten innewohnende Göttliche, bei Christus die zweite Person des dreifaltigen Gottes, bei der Kirche jene göttliche Wirklichkeit, deren der Mensch als Glied der sichtbaren Kirche teilhaftig werden soll und die wir repräsentativ ,Heiliger Geist" als Seele der Kirche nennen", O. Semmelroth, Die Kirche als Ursaterament, Frankfurt am Main ${ }^{3} 1963,25-26$.

9 Méditation sur l'Eglise, (Théologie 27), Paris 1953, 175. 
Oczywiście, jest wiele możliwości więcej lub mniej odpowiedniego ujęcia językowego sakramentalnej formuły eklezjologicznej. Wszystkie jej wersje, od najbardziej ogólnych aż do wypracowanych w szczegółach, powinny jednak być odnotowane i przeanalizowane, jeżeli się pragnie wszechstronnie zgłębić problem sakramentalności Kościoła, a zwłaszcza poznać, jak ją sobie wyobrażali ludzie zaangażowani w dzieło II Soboru Watykańskiego. W niniejszym studium będzie chodziło - co już zaznaczyliśmy na początku - o przyjrzenie się jej tylko w okresie przedprzygotowawczym (1959-1960) do Vaticanum II.

\section{2. ŹRÓDEA.}

W kilka miesięcy po zapowiedzi zwołania Soboru (25. 1. 1959) ${ }^{10}$ papież Jan XXIII ustanowił 17. 5. 1959 Komisję przedprzygotowawczą powszechnego Soboru (Commissio antepraeparatoria pro Concilio oecumenico), do której zadań należało:

- podjęcie kontaktów z katolickim episkopatem różnych narodowości celem zasięgnięcia rady i otrzymania sugestii;

- zebranie propozycji sformułowanych przez dykasterie Kurii Rzymskiej;

- naszkicowanie ogólnych zarysów problematyki soborowej, wysłuchawszy również zdania wydziałów teologicznych i uniwersytetów katolickich;

- zaproponowanie składu różnych organów (komisji, sekretariatów, itp.), które z kolei podjęłyby się bliższego przygotowania prac, dla jakich Sobór zostanie zwołany.

$\mathrm{Na}$ czele Komisji przedprzygotowawczej, liczącej dziewięciu członków, stanął kard. D. Tardini, sekretarz stanu. Jej sekretarzem został Mons. P. Felici, audytor Roty Rzymskiej ${ }^{11}$.

10 Primus oecumenici Concilii nuntius, w: Acta et Documenta Concilio oecumenico Vaticano II apparando. Series I (Antepraeparatoria) (= S. A.), vol. I: Acta. summi Pontificis Joannis XXIII, TPV 1960, 3-6. ,Venerabili Fratelli e Diletti Figli! Pronunciamo innanzi a voi, certo tremando un poco di commozione, ma insieme con umile rizolutezza di proposito, il nome e la proposta della duplice celebrazione: di un Sinodo Diocesano per l'Urbe, e di un Concilio Ecumenico per la Chiesa universale". Tamże, 5. Por. także AAS, 51 (1959) 65-69. - Uroczyściej papież Jan XXIII zapowiedział zwołanie Soboru (Sollemnior Concilii oecumenici nuntius) w swojej pierwszej Encyklice Ad Petri cathedram, z 29. 6. 1959, gdzie opisujac cele Soboru dużo mówił o jedności Kościoła, do której wezwał także odłaczonych braci. $S$. A., vol. I, 33-39. Por. AAS, 51 (1959) $498 \mathrm{nn}$. - Wreszcie, w przemówieniu wygłoszonym 7. 12. 1959 w rzymskiej bazylice Dwunastu Apostołów, Jan XXIII oświadezył po raz pierwszy, że zapowiedziany Sobór będzie nazywał się "Vaticano II", - II Soborem Watykańskim. S. A., vol. I, 60: ,Il Pontefice della Chiesa di Cristo tiene rivolte verso il Concilio Ecumenico, che sarà il Vaticano II, le sue più alte e più vaste sollecitudini. La quadruplice denominazione della Chiesa, una santa, cattolica ed apostolica, dà il tocco preciso delle proporzioni del grande avvenimento". Por. „L'Osservatore Romano”, 9-10 dicembre 1959.

11 Constitutio Commisionis antepraepatoriae, w: S. A., vol. I, 22-23. Por. ,L'Osservatore Romano", 17 maggio 1959. 
Spełniając swoje zadania Komisja przedprzygotowawcza wysłała wczesnym latem 1959 trzy różne pisma z prośbą o nadesłanie wypowiedzi na temat Soboru do wiosny 1960. Adresatami ich byli: biskupi i prałaci ${ }^{12}$, kongregacje Kurii rzymskiej ${ }^{13}$, kościelne uniwersytety oraz wydziały katolickie ${ }^{14}$. Wypowiedzi te stanowią gros Seri przedprzygotow a w c z e j źródeł do studiów nad Vaticanum II, a mianowicie woluminy II, III, IV Akt i Dokumentów przygotowy wanego II Soboru Watykańskiego (Acta et Documenta Concilio oecumenico Vaticano II apparando. Series I (Antepraeparatoria)). Zostały one wydane

12 List do biskupów i prałatów został wysłany 18. 6. 1959. Istotny jego passus brzmial: ,Rogo igitur enixe Excellentiam Tuam communicare faveas huic Pontificiae Commissioni, omni cum libertate et sinceritate, animadversiones consilia et vota, quae pastoralis sollicitudo zelusque animarum, Excellentiae Tuae suggerant circa res et argumenta quae in futuro Concilio tractari poterunt. - Huiusmodi res et argumenta possunt sive quaedam doctrinae capita, sive disciplinam cleri et populi christiani, sive actuositatem multiplicis generis, qua hodie Ecclesia tenetur, sive negotia maioris momenti, quae eadem Ecclesia obire hodiernis debet temporibus, sive denique caeteras omnes res quas Excellentiae Tuae exponere et enucleare vivum fuerit", S. A., vol. II, par I: Europa (Anglia - Germania), TPV 1960, X. Zob. także list z 21. 3. 1960, przedłużający biskupom i prałatom na okres kwietnia tegoż roku termin nadsyłania odpowiedzi. Tamże, XIII.

13 W liście z 29. 5. 1959 Kard. D. Tardini soborowe zadania przygotowawcze dykasterii rzymskich widział następująco: ,A tal proposito credo doveroso chiarire che il lavoro che le Sacre Congregazioni sono chiamate a svolgere in vista del Concilio Ecumenico deve svilupparsi, per così dire, in due fasi. La prima, quella più immediata e che richiede una comprensibile celerità, sta nella revisione della posizione in stampa che viene ora consegnata all'Eccellenza Vostra... - L'altra fase di lavori, che è bene abbia inizio quando primo, importa invece uno studio largo e profondo di tutti quei problemi di competenza delle singole Congregazioni, che si crede utile portare in discussione o far presenti alle future Commissioni Preparatorie del Concilio Ecumenico. In questa seconda fase e, come è intuitivo, solo in questa entreranno in funzione le Commisioni di studio di cui si e fatto parola nell'adunanza e che saranno composte di Consultori, di Consigieri, di Aiutanti di studio ecc.", S. A., vol. III: Proposita et Monita SS. Congregationum Curiae Romanae, TPV 1960, X. Sam termin nadesłania odpowiedzi dokładnych i dobrze umotywowanych (ben precise e motivate) Kard. D. Tardini wyznaczył w innym liście (16. 2. 1960) na połowę marca tegoż roku. Tamże, XIII, Dykasterie Kurii rzymskiej opracowały swoje odpowiedzi po konsultacji materiałów nadesłanych przez biskupów i prałatów. Materiały te były im udostępniane w formie specjalnie opracowanych fiszek (schede) przez Sekretariat Komisji przedprzygotowawczej. Tamże, XIXII; XIV-XV.

14 List datowany 18, 6. 1959 otrzymali rektorzy uniwersytetów (Rectores) i dziekani (Praesides') kościelnych wydziałów katolickich. Skierowana do nich prośba brzmiała następująco: ,Rogo igitur Magnificentiam Tuam ut, collatis consiliis atque consociatis studiis cum Facultatum a te dependentium Magistris, exponas huic Commissioni quid videtur opportunius Concilii Patribus olim proponendum, quave scientifica ratione id possit expendi et enucleari, quibusve practicis modis ad exsecutionem perduci. - Materiae, in quas studium feratur, variae esse possunt: dogmaticae in primis, biblicae, liturgicae, philosophicae, morales et iuridicae, pastorales, sociales etc. Agi quoque potest de disciplina cleri et populi christiani: de seminariis, de scholis, de actione catholica: de alisque rebus quae Tibi videantur Ecclesiae animarumque bono profuturae. Attamen, ut evidens est, non omnes materiae neque omnia argumenta $a b$ ornibus examini et studio subicientur: rerum inter multa, ea seligat Magnificentia Tua quae cum maxime Ecclesiae prodesse existimantur tum etiam a Magistris Facultatum a Te dependentium melius et enucleatius tractari poterant", S. A., vol. IV, pars I/1: Universitates et Facultates in Urbe, TPV 1961, XI-XII. Czas na odpowiedź był dany do końca kwietnia 1960. 
drukiem sub secreto, staraniem Sekretariatu papieskiej Komisji centralnej przygotowawczej Vaticanum II. Uwagę czytelnika zwracają nagłówki poszczególnych woluminów oraz ich ilościowe zróżnicowanie. Opinie biskupów i prałatów, zebrane w woluminie II a zatytułowane $\mathrm{R}$ a dy i W ot a (Consilia et Vota), liczą osiem części (pars), czyli tomów, plus dwa tomy Apendyksu (Appendix), podającego indeks analityczny (analyticus conspectus) do całości tego materiału. Drugim co do wielkości jest wolumen IV, podzielony na dwa tomy, które obejmują Studia i Wota (Studia et Vota) kościelnych uniwersytetów i wydział́ów katolickich. Odpowiedzi dykasterii Kurii rzymskiej nazwane Propozyc jami i Uwagami (Proposita et Monita) mieszczą się w jednotomowym woluminie III. W skiad woluminu I, także jednotomowego, wchodzą Akta (Acta) papieża Jana XXIII z lat 1959-1960, dotyczące Soboru. Serię zamyka tom indeksowy (Indices). Całość liczy siedemnaście tomów. $\mathrm{Na}$ duże uznanie zasługuje szybkość, z jaką dokonano publikacji całości kolekcji. Została wydana w przeciągu dwóch lat: 1960-1961, tak, by służyé soborowym pracom przygotowawczym.

Ilościowo największy a treściowo najbogatszy zestaw materialów okresu przedprzygotowawczego Vaticanum II stanowią zatem wypowiedzi biskupów i prałatów oraz wyższych przełożonych zakonnych (generałów). Zbierająca je Seria przedprzygotowawcza zawiera, jak widzieliśmy, tzw. Apendyks, podający w dwóch tomach indeks analityczny tych wypowiedzi ${ }^{15}$. Ten pierwszy ich rekonesans treściowy ujawnił bardzo wyraźnie niezwykłą aktualność problematyki eklezjologicznej w świadomości episkopatu światowego. Jeżeli się pominie kwestię stosunków: Kościół - państwo (De Ecclesia et statu) i naukę społeczną Kościoła (De sociali doctrina Ecclesiae), potraktowane w Apendyksie odrębnie ${ }^{16}$, to sam rozdział o Kościele (De Ecclesia) obejmuje pod dwudziestu ośmiu tytułami dwieście pięćdziesiąt różnych haseł ${ }^{17}$.

Jednakże Apendyks w swoim indeksie nie zawiera wniosków nadesłanych przez dykasterie Kurii rzymskiej oraz katolickie uniwersytety i wydziały teologiczne i $\mathrm{w}$ konsekwencji nie reasumuje pełnego obrazu katolickiej świadomości eklezjalnej. Nadto, podany przezeń indeks nie zadowala pod każdym względem. Było zatem celowe podjęcie własnych poszukiwań danych potrzebnych do wyświetlania sakramentalności Kościoła w całości materiału przedprzygotowawczego. Zgodnie z przewidywaniami przyniosło ono bardzo poważne uzupełnienie informacji Apen-

15 Series antepraeparatoria. Appendix Voluminis II: Analyticus Conspectus Consiliorum et Votorum quae ab Episcopis et Praelatis data sunt. Pars I; pars II, TPV 1961.

is Pars I: Doctrinae Capita - Normae Generales C. I. C. - De Personis - Disciplina Cleri - De Seminariis - De Religiosis - De Laicis, 81-99; 100-118.

17 Tamże, 35-80. 
dysku w tym zakresie, a zwłaszcza odkrycie samej formuły określającej Kościół jako sakrament ${ }^{18}$.

Przystępując do szkicu sakramentalnej koncepcji Kościoła zawartej w Series antepraeparatoria należy zdawać sobie sprawę zarówno z reprezentatywności jak i specyficzności tego materiału. Teksty dokumentacji przedprzygotowawczej mają za autorów cały episkopat Kościoła katolickiego, dykasterie Kurii rzymskiej i wyższe uczelnie katolickie. W tym stanie rzeczy trudno sobie wyobrazić bardziej reprezentatywny i kompletny sondaż opinii Kościoła. Złożone jednak głosy mają zasadniczo charakter krótkich haseł, postulatów czy deklaracji. Nie były to z reguły jakieś pogłębione studia na określony temat, choć i takie się zdarzały ${ }^{19}$. Cały ten materiał został $\mathrm{w}$ naszym studium potraktowany na równych prawach, jako świadectwo i wyraz jednej i tej samej wiary Kościoła katolickiego anno Domini 1959-1960. Tego rodzaju podejście do dokumentacji przedprzygotowawczej Vaticanum II nie chce jednak nic mówić i faktycznie nic nie mówi o kwalifikacji teologicznej poszczególnych wypowiedzi. Ta na pewno jest zróżnicowana, ale stanowiąc problem sam w sobie, nie dotyczyła wprost podjętego tematu.

Sakramentalność Kościoła, jaka się wyłania z całości dokumentacji przedprzygotowawczej Vaticanum II, posiada bardzo różne oblicza. Przede wszystkim i najczęściej zarazem występuje w postulatach domagających się od zapowiedzianego Soboru takiej wizji Kościoła, która by harmonizowała jego stronę zewnętrzną i wewnętrzną, ziemską i niebieską, naturalną i nadprzyrodzoną w jedną nadrzędną złożoną całość. Ta najogólniejsza forma sakramentalnego charakteru Kościoła swoją bliższą konkretyzację znajduje tam dalej w uwypukleniu przez szereg głosów aspektów chrystologicznego i pneumatologicznego rzeczywistości eklezjalnej. Są w końcu i takie teksty, które równoznacznie czy równoważnie, a nawet całkiem wyraźnie, swoim określeniem Kościoła implikują różne formy pojęcia sakramentu znane $z$ Biblii i z tradycji doktrynalnej. Kluczem, który niejako do końca pozwala zgłębić tak zaprezentowany Kościół może być - czemu dało wyraz również wielu respondentów - tylko wiara.

18 Por. także: L. Boff, Die Kirche als Sakrament im Horizont der Welterfahrung, Padeborn 1972, 229-231. Kwerenda Boffa w materiale okresu przedprzygotowawczego Vaticanum II na temat sakramentalności Kościoła, jedyna z przeprowadzonych dotychczas, była raczej pobieżna, o czym świadczy dowodnie bardzo ogólny charakter jego wniosków i skromna baza tekstowa, na której zostały oparte.

${ }_{19}$ Przykładowo wymienię uwagi M. kard. Fossatiego, abpa Turynu, który powołał specjalną komisję diecezjalną dla opracowania swoich propozycji. Propozycje te podpisane przez samych autorów są niekiedy prawdziwymi studiami problemów. S. A., vol. II, pars III: Europa (Italia), TPV 1960, 872. Częściej charakter studiów mają wota kościelnych uniwersytetów i wydziałów katolickich. Znowu przykładowo cytuję głos Pontificia Universitas Manilensis Sancti Thomae. S. A., vol. IV, pars II: Universitates et Facultates extra Urbem, TPV 1961, 253-416. 


\section{POSTULAT PEENEJ WIZJI KOSCIOEA.}

Uwagę czytelnika Series antepraeparatoria najwięcej przykuwa w tekstach podejmujących zagadnienia eklezjalne postulat pełnej wizji Kościoła. Jest przy tym rzeczą charakterystyczną, że postulat ów występuje tam z reguły w kontekście naturalizmu eklezjologicznego. Niebezpieczeństwo tego naturalizmu widzi się często, pisze się o nim i proponuje wyraźne odcięcie od niego. Tak np. bp P. M. Lacointe wraz z innymi uskarżał się na pomniejszenie zmysłu nadprzyrodzonego u ludzi, co w konsekwencji bardzo utrudnia współczesnym chrześcijanom wàaściwe zrozumienie posłannictwa Kościoła. Ludzie współcześni bowiem spieszą się, chcą widzieć, dotykać, eksperymentować, stwierdzać. Dlatego w Kościele dostrzegają często tylko potężną organizację i administrację, zarzucając mu trzymanie się przestarzałych form działania i brak skuteczności. A tymczasem Kościół ma za zadanie kontynuować dzieło zbawcze Chrystusa, przez łaskę zbawiać człowieka i świat. Z natury rzeczy więc działalność jego wymyka się w znacznej mierze doświadczeniu ludzkiemu. Będąc powolną i dyskretną, idzie w zamian za to w głąb. Sens Kościoła gubią ludzie, na skutek utraty sensu Boga i grzechu 20. W przeciwieństwie do tego stanu rzeczy mistycyzm eklezjologiczny, akcentujący do przesady element boski w Kościele przez stawianie znaku równości pomiędzy Chrystusem i Kościołem, mimo występowania, nie jest sygnalizowany w dokumentacji przedprzygotowawczej jako realne zagrożenie Kościoła.

Stąd nie powinnien dziwić fakt, że w Kościele jako społeczności (societas) został podkreślony przez wiele odpowiedzi jej nadprzyrodzony i zbawczy charakter. W ich opinii, owszem, Kościół jest ,widzialnym zrzeszeniem”, ,widzialną społecznością" 21, ,instytucją zbiorową, gdzie podstawy życia zorganizowanego, porządek i sprawiedliwość, są oparte na Piotrze i Apostołach" 22, ale jest to zarazem ,,społeczność ludzko-boska" 23, „,jakby rzecz ludzko-boska” sprowadzająca wszystko do wspaniałej i skutecznej jedności ${ }^{24}$, ,społeczność, poprzez której wewnętrzną strukturę lu-

20 S. A., vol. II, pars I, 212-213 (Galia - Beauvais). Tekst bpa P. M. Lacointe z niewielkimi zmianami przytaczają jeszcze dwaj abpi francuscy: J. Lefebre z Bourges (tamże, 239-242) oraz A. Marmottin z Reims (tamże, 375-376). Na istnienie niebezpieczeństwa naturalistycznej wizji Kościoła między innymi uskarżali się mocno także: bp H. Poletti, S. A., vol. II, pars III, 872 oraz dwaj wyżsi przełożeni zakonni: C. Heiligers i E. Déage (S. A., vol. II, pars VIII: Superiores Generales Religiosorum, TPV 1961, 154; 174).

${ }_{21}$ S. A., vol. IV, pars II, 620 (Universitas Catholica Americae Washingtonensis).

22 S. A., vol. IV, pars I/1, 344 (Pontificia Universitas Lateranensis. Facultas iuris canonici).

${ }_{23}^{23}$,Societas humano - divina”, S. A., vol. II, pars III, 451 (G. V. Gremigni: Italia).

$\mathbf{2 4}^{4}$ „Ecclesia Catholica Apostolica Romana velut res humano - divina quae ad unitatem excelsam et efficacem quam maxime omni connectit", S. A., vol. II, pars III, 334 (C. Stella: Italia). 
dzie są jakby żywymi kamieniami tworzącymi duchowy dom i święte kapłaństwo dla składania ofiar” 25, ,społeczność doskonała”, dzięki której Boski Odkupiciel pozostaje wśród ludzi jako Kapłan, Nauczyciel i Król ${ }^{26}$, „,poprzez którą Boże odkupienie dosięga narody” 27. Jako taka społeczność Kościoła jest ,wspólnotą” (communio) zapewniającą wszystkim złączonym z Chrystusem i apostołami, ze względu na pośrednictwo następców apostolskich i zastępcy Chrystusa udział w najwyższych dobrach 28: ,zbiorową organizacją łask" i ,przekazem tajemnic Bożych" 29, ,z wyboru Bożego konieczną i wyłączną racją otrzymanej łaski" 30. Wszyscy wierni mają obowiązek w Kościele widzieć coś więcej niż tylko zwykłą, ,instytucjęe" pomagającą im w osobistym zbawieniu, tzn. czuć się członkami jedynego Ciała Chrystusowego ${ }^{31}$.

$\mathrm{Na}$ tym tle lepiej zrozumiałe stają się także te gìosy, skierowane pod adresem Soboru, które wyraźnie postulowały przy określaniu Kościoła równomierne uwzględnienie wszystkich aspektów jego rzeczywistości, czyli żeby przy zajmowaniu się stroną ziemską Kościoła nie zapominano o jego wymiarze transcendentnym. I tak bp L. Castán Lacoma żądal ,poprawnej doktryny o wewnętrznej i nadprzyrodzonej konstytucji Kościoła, o jego misterium, mocą którego jest Ciałem Mistycznym Chrystusa i wykracza daleko poza wszystkie inne ludzkie społeczności" 32. Sobór ,powinien zdefiniować - o co dopominał się z kolei J. B. kard. Montini, obecny papież, Paweł VI - powiązania istniejące pomiędzy wewnętrzno-nadprzyrodzonym życiem Kościoła i jego hierarchiczną strukturą, celem dania dokładnej i pełnej nauki o prawdziwej naturze Kościoła i o związkach, jakie z nim mają wszyscy ochrzczeni, i ci, którzy w dobrej wierze znajdują się poza Kościołem; te bowiem związki bywają rozpatrywane częściej w porządku prawnym, aniżeli w porządku ontolo. gicznym” 33. Według bpa A. M. I. Durrieu, prezentację ,autentycznego pojęcia Kościoła” na Soborze koniecznie trzeba podjąć, ponieważ ,jurydyczny gmach Kościoła, kryje pod swą widzialną osłoną tajemnicę obec-

25 S. A., vol. II, pars VIII, 174 (E. Déage: Superior generalis Missionariorum S. F. Salesii de Annecio).

26 S. A., vol. 11, pars VI: America Septemtrionalis et Centralis, TPV 1960,342 (P. Schulte: USA).

27 S. A., vol. II, par IV: Asia, TPV 1960, 565 (L. Lacoste: Sinae).

28 S. A., vol. II, pars V, 146 (K. Toussaint: Congo).

29 ,Socialis organisatio gratiarum: communicatio mysteriorum Dei", S. A., vol, II, pars $T$, 253 (L. Lacoste).

30 S. A., vol. IV, pars II, 620 (Universitas Catholica Americae Washingtonensis).

31 S. A., vol. II, pars VIII, 174 (E. Déage).

32 S. A., vol. II, pars II: Europa (Gibraltaria... Turchia Europea), TPV 1960, 421 (Hispania). - Podobna myśl sformułował bp A. S. Tortolo. S. A., vol. II, pars VII: America Meridionalis. Oceania, TPV 1961, 101 (Argentina).

$3:$ S. A., vol. II, pars III, 377 (Italia). - O istnieniu tendencji niebezpiecznego oddzielania Kościoła widzialnego od niewidzialnego pisali: J. B. Megrun, bp Angoulême oraz A. Ancel, bp pomocniczy Lyon. S. A., vol. II, pars I, 141; 507 (Galia). 
ności Ducha Świętego" "34. W wotum Uniwersytetu św. Patryka oznaczało to, że „Kościół jest nie tylko ciałem zbiorowym, lecz także ciałem żywym..., że określają go i łączą również niewidzialne więzie, a mianowicie wewnętrzne i mistyczne życie, dawane jemu i jego członkom przez Ducha Chrystusa" 35. Dlatego, zdaniem bpa T. Raymundos, Kościół zwraca się dzisiaj do całego swego ludzko-boskiego bytu, ponieważ przy asystencji Ducha Swiętego, a więc za dopuszczeniem Bożym, nabył w obecnym czasie lepszą i pełniejszą świadomość samego siebie ${ }^{36}$.

Tę ogólną troskę wielu wypowiedzi o wszechstronnie pogłębioną wizję soborową rzeczywistości eklezjalnej podzieliła także Kongregacja św. Oficjum, odpowiedzialna w szczególniejszy sposób za ortodoksję nauki katolickiej. Opowiedziała się bowiem ona za „Kościołem jednym, widzialnym i niewidzialnym, składającym się ze struktury hierarchicznojurydycznej, a zarazem charyzmatycznym i mistycznym, bez przeciwstawienia, bez zasadniczego dualizmu, tak zwanego Kościoła jurydycznego i Kościoła miłości; za dwoma odrębnymi aspektami jednego i tego samego Kościoła, społeczności doskonałej, żyjącej łaską i charyzmatami Jucna Śxiętego; za Ciałem Mistycznym Chrystusa, nie tylko eschatologicznym, lecz także już teraz obecnym" 37. Przy, uwzględnieniu całej społeczno-organizacyjnej strony Kościoła, „definicja” ta mówi również o jego nadprzyrodzonym życiu na ziemi i eschatologicznej realizacji.

Należy tutaj dodać, że ta pogłębiona i pełna zarazem wizja Kościoła była udziałem nie tylko pewnych jednostek, lecz całego ogółu respondentów. Swiadczy o tym wymownie u nich powszechna akceptacja miana „Mistyczne Ciało Chrystusa” dla Kościoła. W dokumentacji przedprzygotowawczej nazwa „Mistyczne Ciało Chrystusa” jest po prostu synonimem wyrazu Kościól. Ponadto wotum Katolickiego Uniwersytetu Waszyngtońskiego Ameryki Północnej wyjaśniało, że określenie „Mistyczne Ciało" jest czymś więcej niż zwykłą metaforą, sztucznie przeniesioną przez argumentację apologetyczną na strukturę Kościoła. Oczom wiernych odsłania bowiem wewnętrzne i głębokie arkana społeczności Kościoła ${ }^{38}$. Opierając się na danych Apendyksu w tej kwestii można śmiało stwierdzić, że „Ciało Mistyczne Chrystusa” dla ludzi bezpośrednio zaangażowanych $\mathrm{w}$ dzieło Vaticanum II reprezentowało pełnię wartości reli-

${ }_{34}$ S. A., vol. II, pars V: Africa, TPV 1960, 67 (Africa occidentalis - Ouahigouya).

35 S. A., vol. IV, pars II, 432.

36 S. A., vol. II, pars I, 489 (Galia).

37 ,Ecclesia una, visibilis, et invisibilis, constans structura hierarchico - iuridica ac simul ac charismatica et mystica. Nulla oppositio, nulla vera dualitas Ecclesiae, quam dicunt, iuris, et Ecclesiae amoris, sed duo distincti adspectus unius eiusdemque Ecclesiae, societatis perfectae gratia ac Spiritus Sancti charismatibus turgentis. - Corpus Christi Mysticum, non tantum eschatologicum sed etiam praesens", S. A., vol. III, 5 .

38 S. A., vol. IV, pars II, 620. 
gijnych i apostolskich: unię Chrystusa z Kościołem, charakter witalny tej unii, synchronizację aspektu niewidzialno-nadprzyrodzonego $\mathrm{z}$ aspektem widzialno-zewnętrznym, dowartościowanie wszystkich członków Kościoła, a więc nie tylko hierarchii, lecz i katolików świeckich, oraz współpracę między nimi w kontynuowaniu dzieła zbawczego ${ }^{39}$.

Przytoczone wypowiedzi dowodzą, że koncepcja Kościoła zawarta w dokumentacji przedprzygotowawczej Vaticanum II reprezentowała typ eklezjologii zrównoważonej. Charakteryzuje się on z jednej strony przezwyciężeniem tej orientacji, którą $w$ eklezjologii rozwinęła kontrreformacja potrydencka z R. Bellarminem na czele, patrząca na Kościół głównie jako na zorganizowaną społeczność, z częściowym pominięciem jej duchowo-nadprzyrodzonego wnętrza, z drugiej zaś strony ukazywaniem współegzystencji boskiego oblicza Kościoła z jego ziemską rzeczywistością. Niewątpliwie była w tym duża zasługa tego nurtu eklezjologicznego, który dał o sobie mocno znać już w schemacie „De Ecclesia” I Soboru Watykańskiego ${ }^{40}$, a który na szeroką skalę rozwinął się dopiero $\mathrm{w}$ okrẹsie międzywojennym, osiągając swoje apogeum $\mathrm{z}$ ogłoszeniem encykliki „Mystici Corporis Christi” przez papieża Piusa XII, która to encyklika bardzo zdecydowanie napiętnowała i odrzuciła zarówno naturalizm jak i mistycyzm eklezjologiczny ${ }^{41}$. Omówione teksty są świadome tych błędów, zwłaszcza naturalizmu. Dla nauki o sakramentalności eklezjalnej mają one decydujące znaczenie, ponieważ ta istotnie zakłada takie pojęcie Kościoła, które nie jest ani naturalistycznym, ani też mistycyzującym, lecz w jedności niepomieszanej harmonizuje wszystkie jego bogactwa naturalne i nadprzyrodzone, zewnętrzny materialny obraz i wewnętrzną duchową moc, doczesny konkret i Bożą łaskę. Sama zaś formuła nazywająca Kościół sakramentem nie jest niczym innym jak tylko scaleniem tych elementów w jedną nadrzędną całość, pozwalającą człowiekowi pracą swego umysłu przybliżyć sobie misterium rzeczywistości eklezjalnej. Sakramentalne rozumienie Kościoła rodzi się na gruncie pełnej jego wizji, a zarazem stanowi teologiczną próbę bliższego jej określenia.

39 Hasło: „Corpus Christi Mysticum”, S. A. Appendix Voluminis II, pars I, 37; $39 ; 40 ; 41 ; 56 ; 66 ; 68-76 ; 77 ; 78$. - Por. G. Thils, Orientations de la théologie, Louvain, 1958, 96.

40 Rzeczą, która w tym schemacie uderza i stanowi nowość jest I rozdział, noszacy tytuł "Ecclesiam esse corpus Christi mysticum”. Schemat przygotowany pod dyskusję soborową zawierał zatem niektóre prawdy zapoznawane przez eklezjologię instytucjonalną. Co więcej, pojęcie Mistycznego Ciała Chrystusa zostało w nim wysunięte na czoło, jako rodzaj ,definicji" Kościoła. W ten sposób struktura społeczna Kościoła została wypełniona nową nadprzyrodzoną treścią. Por. Schema constitutionis dogmaticae de ecclesia Christi patrum examini propositum, Mansi, T. LI, $539-553$.

${ }^{41} A A S, 35$ (1943) 197. 


\section{CHRYSTOLOGICZNY I PNEUMATOLOGICZNY ASPEKT KOSCIOEA.}

Dla odpowiedniego ujęcia i określenia sakramentalnej struktury Kościoła duże znaczenie mają jego chrystologiczny i pneumatologiczny wymiar ${ }^{42}$. Oba te wymiary wskazują i stanowią zarazem istotne komponenty eklezjalnej sakramentalności. Stąd studium na temat Kościoła jako sakramentu nie może pominąc pytania dotyczącego związków istniejących pomiędzy Kościołem z jednej, a Chrystusem i Duchem Swiętyn z drugiej strony. Im wyrazistsze będzie uchwycenie tych związków, tym samym również zarysowana przezeń wizja sakramentalna Kościoła stanie się pełniejsza. Innymi słowy, eklezjalna sakramentalność wyrastając z chrystologicznych i penumatologicznych podstaw eklezjologii, pozostaje z nimi trwale sprzężona i dlatego tylko na ich gruncie może być właściwie rozpoznana i sformułowana.

Pojęcie Kościoła, jakie się wyłania z tekstów dokumentacji przedprzygotowawczej Vaticanum II z całą pewnością posiada wymienione wyżej cechy, tzn. że jest chrystologiczne i pneumatologiczne, mimo pewnej różnicy w akcentach, jakie na nie położono: większy na chrystologiczny, mniejszy na penumatologiczny, zgodnie zresztą z dotychczasową orientacją teologii katolickiej.

Jeżeli idzie o więź łączącą Chrystusa i Kościół, to poszczególne wypowiedzi stwierdzają najpierw tradycyjny obraz tej więzi, tzn. Chrystus Pan, jest przedstawiany jako Założyciel i Głowa Kościoła. „Kościćł w swoim ziemskim stanie, jako zrzeszenie widzialne - pisał bp F. Baldelli - był już chciany w odwiecznym planie stwórczym Boga, który na nowo został potwierdzony przez objawienie Jezusa" ${ }^{43}$. W czasie i przestrzeni - według sformułowania Waszyngtońskiego Uniwersytetu Katolickiego - „Kościół (po prostu) narodził się z Chrystusa” ${ }^{44}$. Bp P. Douillard zauważył, że chrześcijanie, i to wcale nie w małej liczbie, wierzą w Chrystusowe ustanowienie Kościoła ${ }^{45}$, a bp M. Buchberger domagał się, żeby Sobór złożył wyznanie wiary w „,́więty Kościół, założony przez Chrystusa” ${ }^{46}$, co bp A. I. Muech nazwał „boskim pochodzeniem Kościoła" ${ }^{47}$.

42 Twierdzac to, nie neguje się istnienia w soborowej dokumentacji przedprzygotowawczej tekstów ukazujących związki Kościoła z Bogiem Ojcem i całą Trójcą Swiętą. Swiadczą o tym zwroty: „Familia Dei Patris”, „Dei Regnum”, „Populus Dei”, S. A. Appendix Voluminis II, pars I, 37; 78, czy mówienie o „Ecclesia ut Patris caelestis novus acquisitionis populus, Christi Capitis dilectissima Sponsa et Corpus Mysticum, Spiritus Sancti vivens in terris templum", S. A., vol. II, pars IVII, 100 A. S. Tortolo).

${ }_{43}$ S. A., vol. II, pars III, 789 (Italia).

44 S. A., vol. IV, pars II, 619.

45 S. A., vol. II, pars I, 405 (Galia).

46 S. A., vol. II, pars I, 656 (Germania).

${ }_{47}$ S. A., vol. II, pars I, 677 (Germania). 
Tym boskim pochodzeniem cieszy się osobliwie cały widzialny ustrój Kościoła 48. Od Chrystusa wywodzą się bowiem jego wszystkie istotne elementy: prymat, episkopat, kapłaństwo, a nawet sama godność chrześcijańska wiernych, otrzymywana wraz z niezatartym znamieniem chrztu, który jest Bożym skutkiem, boskiego a nie kościelnego rytu ${ }^{49}$. Tego to Kościoła Chrystus jest Głową ${ }^{50}$. Głowę i Ciało Chrystusa łączy więź miłości ${ }^{51}$.

Ale w przekonaniu licznych głosów relacje „Chrystus - Kościól” idą jeszcze dalej i głębiej: przypominają teandryzm Jezusa Chrystusa. Kościół jest zbudowany na wzór bosko-ludzkiej struktury, stanowiąc w pewnej mierze prawdziwe i rzeczywiste odbicie unii hipostatycznej jednoczącej naturę boską i ludzką w Chrystusie.

I tak, zdaniem wotum Katolickiego Uniwersytetu z Lille, „Ciało Mistyczne Chrystusa utożsamiając się z Kościołem rzymskim tak, że nie można nigdy mówić o dwóch Kościołach, ale o jednym, widzialnym i niewidzialnym, zarówno boskim jak i ludzkim, do pewnego stopnia ponawia i przedłuża misterium Chrystusa" 52 . Inne głosy to "ponawianie i przedłużanie misterium Chrystusa” przez Mistyczne Ciało nazywają „kontynuacją Słowa Wcielonego na ziemi, rozwijającą dalej unię Boga z ludźmi w Jezusie Chrystusie" 53, ,jakby przedłużeniem Wcielenia Chrystusa" 54, ,poszerzeniem Chrystusa w świecie” 55 , „Chrystusem kontynuowanym w czasie" 56, „samym Chrystusem wśród nas" ${ }^{57}$. Tą swoją „,do Chrystusa podobną i przez Chrystusa daną konstytucję - oświadczył Papieski Instytut Studiów Orientalnych - w pełni odpowiadającą elkonomii Wcielenia, Kościół powinien święcie strzec" 58.

48 S. A., vol. II, pars II, 431 (R. Gonzáles Moralejo: Hispania).

49 S. A., vol. II, pars II, 365 (M. O. Loizaga: Hispania).

$50 \mathrm{~W}$ wielu wypowiedziach. Przykładowo: S. A., vol. II, pars I, 442 (E. J. Le Bellec: Galia); tamże, 629 (M. Keller: Germania); vol. II, pars II, 365 (M. O. Loizaga). vol. II, pars III, 330 (B. L. Migliorini: Italia'); vol. II, pars (VII, 100 (A. S. Tortolo); vol. II, pars VIII, 174 (E. Déage).

51 S. A., vol. IV pars II, 497 (Universitas Catholica Parisiensis. Facultas Theologica).

52 S. A., vol. IV, pars II, 183

53 "Corpus Mysticum Christi, quod est continuatio Verbi Incarnati in terris. Per Corpus Mysticum protrahitur unio Dei et hominis in Christo Jesu", S. A., vol. II, pars VI, 490 (A. Marx: USA').

${ }_{54}$, ,Tractare de Ecclesia ut corpore mystico Christi et quasi prolongatione Incarnationis Christi", S. A., vol. II, pars VI, 61 (J. A. Martin: Canada). - Por. tamże, 64 (M. J. Lemieux: Canada); 109 (G. Cabana: Canada').

5.5 „L'Eglise vue comme l'extension du Christ dans le monde”, tamże, 155 (L. Blais: Canada).

${ }_{56}$ „Aspectus quidem administrativus nonnumquam suffocare videtur sacrum hunc characterem Ecclesiae, quae revera, Christus est in tempore continuatus", S. A., vol. II, pars VIII, 154 (C. Heiligers').

57 „Ecclesiam esse Ipsum Christum apud nos", S. A., vol. II, pars VI, 409 (D. I. Feeney: USA).

${ }_{58}$ S. A., vol. II, pars I/1, 145. 
Na tym tle lepiej stają się zrozumiałe wypowiedzi, które żądają wprost od eklezjologicznego schematu soborowego, aby ,,teologię Kościoła (czy to pasterzy, czy téz wiernych) przedstawił jako kontynuację żywej obecności Chrystusa w nowym ludzie Bożym" (A. S. Tartolo) ${ }^{59}$, bezrvzględnie przestrzegał ,struktury chrystologicznej eklezjologii jako swej naczelnej idei (Fuldańska Konferencja Episkopatu) ${ }^{60}$, dokładnie określił ,,wewnętrzną istotę teandryczną" Kościoła (M. Keller) ${ }^{61}$ : ,teandryzm Chrystusa i Kościoła" (Kongregacja Sw. Oficjum) ${ }^{62}$. Tą drogą soborowa deklaracja ogłaszająca, ,identyczność Chrystusa z jego Kościołem i zarazem zjednoczenie Chrystusa z jego członkami w Kościele" mogłaby — zdaniem bpa V. P. Kellenberga - rozproszyć wiele obiekcji, które mają protestanci względem katolickiej nauki na temat kościelnego pośrednictwa pomiędzy czlowiekiem i Bogiem ${ }^{63}$.

Jednakże, przy całym akcentowaniu relacji tożsamości Chrystusa z Kościołem, występuje w badanej dokumentacji również bardzo wyraźnie świadomość odmienności Kościoła w stosunku do Chrystusa. Swój najpełniejszy wyraz znalazło to w nazwie ,Oblubienica Chrystusa" na Kościół ${ }^{64}$. Wiadomo bowiem, że nazwa ta obok ścisłej unii Chrystusa z Kościołem, stwierdza zarazem, że Kościół różni się od Chrystusa, jak Oblubienica od swego Oblubieńca, że związki zachodzące pomiędzy nimi wyrażają się w kategoriach miłości, wierności i posłuszeństwa.

Podkreślając wymiar chrystologiczny eklezjologii głosy dokumentacji przedprzygotowawczej Vaticanum II nie zapominają bynajmniej o obecności i działaniu Ducha Swiętego w Kościele. Duch Swięty jest przez nie przedstawiany jako rodzaj osobowej entelechii, a więc życiodajnej siły, którą druga Osoba Boża współkształtuje i ożywia od wewnątrz organizm Kościoła.

Bp E. J. Le Bellec powiada, że Kościół stanowi ,społeczność duchową, którą Chrystus, jej Głowa, ożywia przez swojego Ducha Świętego ${ }^{65}$. Według Uniwersytetu Katolickiego „Lowanium” (Léopoldville) Kościół jest ,Ciałem Mistycznym Chrystusa, nowym wybranym Ludem Bożym ... nieustannie ożywianym przez Ducha Świętego, który jest Duchem Chry-

59 S. A., vol. II, pars VII, 101.

60 ,Haec structura christologica Ecclesiologiae omnino servetur et ut principium totius novi schematis elaborandi sumatur", S. A., vol. II, pars I, 745.

${ }_{61}$,Quoad naturam Ecclesiae ... intima eius essentia theandrica plenius describatur', S. A., vol. II, pars I, 629 .

62 "Theandrismus Christi et Ecclesiae", S. A., vol. III, 5.

63 "Declaratio identitatis Christi cum Ecclesia Sua et simul unionis Christi cum membris Suis in Ecclesia", S. A., vol. II, pars VI, 420 (USA).

64 Por. przykladowo: S. A., vol. II, pars I, 629 (M. Keller); vol. II, pars III, 749 (M. Bergonzini: Italia); vol. II, pars VII, 100 (A. S. Tortolo); vol. IV, pars II, 497 (Universitas Catholica Parisiensis. Facultas Theologica).

6.5 S. A., vol. II, pars I, 442. 
stusa” ${ }^{66}$. Bp J. I. Weber to samo stwierdza mówiąc, że „niewidzialnie Duch Swięty we wszystkich działa" 67 .

To „ożywianie” Duchem Swiętym dokonuje się poprzez łaski, dary, cnoty itp. ${ }^{68}$. Przebywając i działając w Kościele Duch Swięty upodabnia do Chrystusa wszystkich członków Kościoła, wlewa i pomnaża życie łaski w Ciele Chrystusa, pobudza i otacza opieką nauczający Kościół, jest źródłem świętości i żaru apostolskiego u wiernych, aż do świadectwa męczeństwa, którego nie brak i w obecnych czasach. Wszystko to razem wzięte pozwala wierze widzieć Kościół jako społeczność istniejącą i zjednoczoną przez Ducha, którego posłał Pan według swej obietnicy ${ }^{69}$. Innymi słowy, używając sformułowania Mediolańskiego Wydziału Teologicznego, ,teandrycznym, do Chrystusa podobnym, Kościół jest właśnie dlatego, że prócz strony widzialnej, posiada Ducha Świętego jako swoją duszę" 70 .

Dzięki Duchowi Swiętemu Kościół urzeczywistnia konsekrację świata, rozpoczętą już z nadejściem swojej Głowy - Chrystusa ${ }^{71}$. Stąd niektóre głosy ubolewają, że spora część wiernych, mimo iż wyznaje szczególną, boską opiekę Ducha nad objawioną nauką i biegiem historii zbawienia, pozostaje nieświadoma lub nie pamięta głębszej prawdy o działaniu tegoż Ducha w Kościele i przez Kościół ${ }^{72}$.

Przytoczone opinie na temat chrystologicznego i pneumatologicznego wymiaru Kościoła mają, rzecz zrozumiała, swój dalszy i bliższy teologiczny kontekst. W swoim podstawowym nurcie reprezentują nieprzerwaną tradycję doktrynalną, będącą w ostatnim stuleciu także przedmiotem zwyczajnego nauczania papieskiego. Wiadomo bowiem, że już papież Leon XIII (1878-1903) ogłosił nie tylko encyklikę „Satis cognitum” (1896) ${ }^{73}$, formułując doktrynę o Mistycznym Ciele Chrystusa w myśl schematu eklezjologicznego Vaticanum I, lecz także encyklikę „Divinum illud munus" (1897) ${ }^{74}$, w której podjął się wszechstronnego naszkicowania roli Ducha Swiętego w Kościele. Również eklezjologia encykliki „Mistici Corporis Christi” była zarówno chrystologiczna jak i pneumatologiczna ${ }^{75}$. Wpływ wymienionych dokumentów papieskich i całej orien-

66 S. A., vol. $I V$, pars $I I, 166$.

67 S. A., vol. II, pars I, 415 (Galia).

68 S. A., vol. II, pars II, 365 (M. O. Loizaga).

69 S. A., vol. IV, pars II, 497 (Universitas Catholica Parisiensis. Facultas Theologica).

70 ,Eclesia, eo quod parte visibili et Spiritu Sancto ut anima componatur, natura est theandrica, Christo similis", S. A., vol. IV, pars II, 680.

71 S. A., vol. II, pars I, 629 (M. Keller).

72 Por. np. S. A., vol. II, pars I, 405 (P. Douillard).

73 Leo XIII, Ep. encycl. "Satis cognitum”, 29 - Iun. 1896, DS 3300-3310; por. ASS, $28(1895 / 96) 709 \mathrm{nn}$.

74 Leo XIII, Ep. encycl. „Divinum illud munus”, 9 Maii 1897, DS 3325 - 3331 ; por. ASS, $29(1896 / 97) 646 \mathrm{nn}$.

75 Holbök, Das Mysterium der Kirche in dogmatischer Sicht, 308. 
tacji eklezjologicznej, której one były wyrazem, jest tutaj niewątpliwy. Dowodzi tego ich tożsamość treściowa, a niekiedy nawet ujęcia słowne tematu. Niemniej trzeba stwierdzić, że nauka wypowiedzi dokumentacji przedprzygotowawczej Vaticanum II w kwestii chrystologicznego i pneumatologicznego charakteru Kościoła jest ogólna i mało sprecyzowana. Nie podejmuje się w niej problemów szczegółowych, a zwłaszcza kontrowersyjnych. Podając doktrynę, nie troszczy się zbytnio o jej zgłębienie.

U niektórych autorów, głównie z Kanady, widać wyraźnie tendencję mistycyzującą. Podobieństwo Kośaioła z Chrystusem niewątpliwie istnieje, lecz nie wolno zapominać, że ma ono również swoje granice, zakreślone dogmatem chrystologicznym, i tych granic nie można ani nie dostrzegać, ani też lekceważyć, czy z nimi się nie liczyć. Radykalność pewnych powiedzeń utożsamiających bez bliższych wyjaśnień Chrystusa i Kościół, okaże się jednakże mniej jaskrawa, jeżeli się zważy ich specyficzny „rodzaj literacki” i że są one niejako wyrwane z kontekstu całości doktryny katolickiej, którą z pewnością podświadomie zakładają i w świetle której konsekwentnie powinno się je rozumieć. Że kryją w sobie wielkie bogactwo treściowe - świadczy rozmaitość ich ujęć.

Miejsce i zadania Ducha Swiętego w Kościele zostały określone w omawianych głosach z pomoca tradycyjnego obrazu „duszy Kościoła”. Oznacza to, że Duch Swięty spełnia w Kościele rolę analogiczną do tej, jaką odgrywa dusza u człowieka. Jako niestworzona, boska, transcendentna i równocześnie immanentna zasada, Duch Swięty czyni Ciało Kościoła wraz z członkami, które zamieszkuje — świętym, żywym, stale zjednoczonym ze swoją Głową-Chrystusem, gwarantując tym samym autentyczność i skuteczność jego ziemskiej egzystencji i misji ${ }^{76}$.

Afirmując chrystologiczną i pneumatologiczną wizję Kościoła dokumentacja przedprzygotowawcza Vaticanum II ,szerokim frontem” stoi na stanowisku katolickiej doktryny o bosko-ludzkiej rzeczywistości Koscioła i tym samym implicite opowiada się za jej sakramentalnością. Ta bowiem poprzez swoją naturę implikuje sprzężenie suwerenną decyzją Bożą widzialnego znaku $\mathrm{z}$ nadprzyrodzoną łaską. I choć rodzaj tego sprzężenia w Chrystusie i Kościele jest istotowo różny, to zachodzi między nimi analogia, czyli takie punkty styczne, które pozwalają na zasadzie podobieństwa przenosić twierdzenia powiedziane o jednej stronie na drugą. Jeżeli Chrystus jest nazywany sakramentem, oczywiście w sensie absolutnie jedynym i tylko sobie właściwym, to analogicznie również i Kościół ze swoją teandryczną naturą w jakiejś mierze zasługuje na miano sakramentu.

76 Ep. encycl. „Divinum illud munus”, DS 3328. — Litt. encycl. „Mystici Corporis", DS 3808. 


\section{SAKRAMENTALNY CHARAKTER KOSCIOEA.}

Ponieważ niniejsze studium usiłuje przebadać przedprzygotowawczą dokumentację Vaticanum II pod kątem widzenia formuły eklezjologicznej, utożsamiającej Kościół z sakramentem, należy zapytać się także, czy i w jakiej mierze występuje tam również bezpośrednia świadomość jego sakramentalnego charakteru. Otóż wydaje się, że jeżeli samo istnienie takiej świadomości nie podlega dyskusji, to jednak formy, w których się wyraża, są dość znacznie zróżnicowane, w zależności od pojęcia samego sakramentu, jakie zakładają. Pojęcie to może być bowiem różnie rozumiane: bądź bardzo szeroko, bądź też więcej dosłownie.

a) I tak, sakrament może oznaczać niekiedy nowotestamentalne misterium, ponieważ greckie „mystérion” zostało przełożone w łacińskich tłumaczeriach Nowego Testamentu i w Wulgacie bądź przez „mysterium” (częściej) "7, bądź też przez „sacramentum” (rzadziej) ${ }^{78}$. Stąd wywodzi się koegzystencja znaczeniowa tych słów w łacińskiej tradycji patrystycznej i średniowiecznej. I choć z czasem wyraz sakrament stał się technicznym określeniem dla siedmiu sakramentów, niemniej jednak nigdy nie utracił on całkowicie swego pierwotnego sensu - misterium. Sakrament być może zatem i nowotestamentalnym misterium, czyli najogólniej mówiąc - tajemnicą zbawczego działania Boga wśród luázi na świecie ${ }^{79}$.

Badane teksty dość często mówią właśnie o Kościele jako misterium: o „,misterium Kościoła” lub że „Kościół jest misterium” ${ }^{80}$. Ale trzeba od razu zauważyć, że w oparciu o nie nie wiele da się powiedzieć, co przez to rozumieją. Używając terminu, nie troszczą się zbytnio o jego sprecyzowanie. Misterium bywa nazywana zarówno instytucja, jak i i to na pierwszym miescu - wewnętrzna natura Kościoła ze wszystkimi nadprzyrcdzonymi bogactwami ${ }^{81}$, a więc wspólnota miłości Bożej rozlanej we wszystkich: wspólnota miłości dziecięcej względem Boga i miłości

77 Por. Mt 13, 11; Mk 4, 11; Ek 8, 10; Rz 11, 25; 16, 25; I Kor 2, 7; 4, 1; 1 Kor 2,$7 ; 4,1 ; 13,2 ; 14,3 ; 15,51 ;$ Ef 3,$4 ; 6,19 ; \mathrm{Kol} 1,26 ; 2,2 ; 4,3 ; 2$ Tes 2, 7; 1 Tym 3,$9 ; \operatorname{Ap~} 10,7 ; 17,5$.

78 Por. Ef 1,$9 ; 3,3 ; 3,9 ; 5,32 ; \mathrm{Kol} 1,27 ; 1 \mathrm{Tm} 3,16 ; \mathrm{Ap} \mathrm{1,} \mathrm{20;17,} 7$.

79 Dla całości por.: J. Finkenzeller, Sakrament. III. Dogmengeschichlich, w: LThK, 9 (21964) 220-225; R. Schulte, Die Einzelsakramente als Ausgliederung des Wurzelsakramentes, w: Mysterium salutis, Bd IV/2: Das Heilshandeln in der Gemeinde. Gottes Gnadenhandeln, Einsiedeln-Zürich-Köln 1973, 63-109 (Zur Geschichte des Lebens der Kirche in ihren Sakramenten und der sich daraus entfaltenden Theologie der Sakramente'); Y. Congar, Un peuple messianique. 'L' Eglise sacrament du salut. Salut et libération, Paris 1975, 47-55 (Le <mystérion> appliqué aux sacraments, traduit par 〈sacramentum > dans l'Eglise ancienne). Dane skrypturystyczne w przypisach 77 i 78 są wzięte ze str. 50 p. 7 ostatniego dzielka: Un peuple messianique.

80 S. A., vol. II, pars I, 366 (G. A. Louis: Galia).

81 S. A., vol. II, pars V, 146 (R. Toussaint). 
braterskiej do ludzi, którzy ją tworzą ${ }^{82}$. W gruncie rzeczy - jak stwierdza A. S. Tortolo - jest to dzisiaj jedyna dostrzegalna obecność Boga $\mathrm{w}$ świecie ${ }^{83}$. Poganom, zwłaszcza żydom i mahometanom misterium Kościoła pozostaje niedostępne w swym najgłębszym nurcie życia ${ }^{84}$. Zywe Ciało Chrystusa jest przecież „w tym, co dotyczy jego życia wewnętrznego misterium przez Boga objawionym" ${ }^{85}$, czyli rozpoznawalnym tylko przez wiarę. Sobór powinien je zgłębić i bliżej określić, ponieważ Vaticanum I tę pracę tylko rozpoczęło, ale jej nie zakończyło ${ }^{86}$.

W sumie, Kościół jako misterium oznacza tutaj przede wszystkim to w rzeczywistości eklezjalnej, co wymyka się czysto ludzkiemu poznaniu i doświadczeniu, do czego człowiek ma dostęp ale tylko z pomocą wiary. Ta strona „misteryjna” Kościoła nie występuje jednak nigdy w oderwaniu od jego rzeczywistości ziemskiej: pozostaje z nią stale zjednoczona i nadaje jej głębszy sens. Z kolei strona widzialna Kościoła niejako urealnia to misterium, pozwala mu się objawić na zewnątrz, czyni je własnością człowieka. Na skutek tego w Kościele współegzystują i na siebie wzajemnie oddziałują doczesność i łaska, człowiek i Bóg.

b) Ale pojęcie sakramentu może być także i nieco węziej rozumiane, w sensie jakiegoś „narzędzia” (instrumentu) zbawienia. Takim pojęciem sakramentu w odniesieniu do Kościoła posłużyła się np. Kongregacja św. Oficjum w Liście do abpa Bostonu, dotyczącym sprawy P. Feeneya. W liście tym Kościół został nazwany ,środkiem zbawienia" (medium salutis) i „ogólną pomocą do zbawienia” (generale auxilium salutis) ${ }^{87}$. Te i im podobne określenia zawierają z całą pewnością, bliżej nie sprecyzowaną, ideę skutecznego ,znaku” zbawczego, istotną dla sakramentów w ścisłym znaczeniu tego słowa.

Otóż i pod tym względem omawiane teksty dostarczają interesujących stwierdzeń. - Kościół „pośród rzeczy tego świata wznosi się jakby sztandar zgromadzający oraz jednoczący wszystkie narody i ludy w Chrystusie" 88, ,niby znak podniesiony wśród narodów i zapraszający do sie82 S. A., vol. II, pars III, 789 (F. Baldelli).

83 ,Sub luce huius mysterii unicae scilicet hodiernae Dei in mundo praesentiae sensibilis proponatur Ecclesia", S. A., vol. II, pars VII, 101.

84 S. A., vol. II, pars VI, 281-282 (R. I. Card. Cushing: USA).

85 S. A., vol. IV, pars II, 620 (Universitas Catholica Americae Washingtonensis').

86 S. A., vol. II, pars I, 643 (L. Jaeger: Germania); por. tamże, s. 751 (Conferentia Episcopalis Fuldensis); vol. III, 318 (Sacra Congregatio de Seminariis et Studiorum Universitatibus').

${ }_{87}$ Ep. S. Officii ad archiep. Bostoniensem, 8 Aug. 1949, DS 3868; 3870.

88 S. A., vol. II, pars I, 411 (J. J. Weber). Biskup B. L. Migliorini ,signum et principium verae unitatis" nazywa "realitatem mystici corporis". Tamże, vol. II, pars III, 330-331 (Italia). A. G. M. De Morais Penido powie, że znakiem wśród narodów, który zbiera rozproszonych ze wszystkich stron świata jest ,ipsum mysterium Ecclesiae". Tamże, vol. II, pars VII, 200 (Brasilia). Por. na ten temat Constitutio dogmatica "Dei Filius" de fide catholica I Soboru Watykańskiego, DS 3013 oraz R. Latourelle, Le Christ, Signe de la Révélation selon la Constitution "Dei Verbum", "Gregorianum", 47 (1966) 658-709 (698). T. Camelot, La Chiesa, Sacramento primordiale, „Sacra Doctrina”, 45 (1967) 59-78 (67). 
bie tych, co jeszcze nie uwierzyli" ${ }^{89}$. Dzięki ruchowi biblijnemu, liturgicznemu i ekumenicznemu katolików, tego rodzaju znakiem - w opinii Wydziału Teologicznego Uniwersytetu Gregoriańskiego w Rzymie Kościół staje się i dla chrześcijan odłączonych ${ }^{\mathbf{9 0}}$. - Prawdziwy Kościół Chrystusa jest dalej „drogą zbawienia dla wszystkich ludzi” ${ }^{11}$. Tę „,drogę”, która jest konieczną, a zarazem i „racją” zbawienia - jak powiada głos Katolickiego Uniwersytetu Waszyngtońskiego - stanowi jego widzialna społeczność ${ }^{92}$. - Jest Kościół również i ,,jedynym oraz wyłącznym szafarzem wszystkich środków koniecznych do zbawienia" ${ }^{93}$, owszem - według bpa A. Zuroweste - samym „środkiem zbawienia" 94, ,Środkiem ustanowionym przez Boga - co z kolei stwierdził M. Baudoux - bez którego ludzie nie mogą realizować swego rozwoju nadprzyrodzonego i naturalnego" 95. - Zdaniem kard. B. J. Alfrinka, Kościół katolicki jest także „jakby narzędziem, z pomocą którego na ziemi rozszerza się królestwo Boże" ${ }^{96}$. Dla Kongregacji Soboru jest to ,narzędzie Chrystusa, które oddaje Bogu chwałę, a ludzi uświęca" ${ }^{97}$. Wreszcie Kościół stanowi - w przekonaniu wielu — „źródło życia" 98, „źródło łaski i zbawienia dla wszystkich” "99, ,źródło i podstawę jedności wśród chrześcijan” 100. Tym ,źródłem zbawienia” staje się nauczając, składając ofiarę Mszy św., administrując sakramentami ${ }^{101}$. - Wszystko to razem wzięte, dobrze streszcza Wydział Prawa Uniwersytetu Laterańskiego oświadczając, że Kościół tworzy „organizm, który posiada, daje i podtrzymuje życie", organizm, w którym Jezus Chrystus urzeczywistnia swoje dzieło wśród ludzi. Ludzie bowiem, stawszy się umarli na skutek grzechu Adama, przez wiare i chrzest otrzymują od Chrystusa w Kościele życie, dzięki któremu stają się wolnymi dziećmi Boga i zasługują na chwałę zmartwychwstania ${ }^{102}$.

Określenia powyższe na różny sposób wyrażają pośrednictwo Kościoła w kwestii zbawienia. ,Iunctim”, na które wskazują pomiędzy Koś-

89 S. A., vol. II, pars V, 100 (L. S. Duval: Africa).

${ }^{90}$ „Christiani dissidentes facilius in Ecclesia catholica signum elevatum inter nationes recognoscent, si etiam in posterum diffundetur et augebitur inter catholicos familiaritas cum S. Scriptura (motus biblicus), si liturgia magis magisque vitam fidelium illustrabit atque informabit (motus liturgicus), si fideles magis sentient se responsabiles esse de unione omnium christianorum promovenda (motus oc.umenicus')", S. A., vol. IV, pars I/1, 11 .

${ }_{91}$ S. A., vol. II, pars VI, 339 (J. M. Gilmore: USA).

92 S. A., vol. IV, pars II, 620.

93 S. A., vol. II, pars I, 356 (J. Girbeau: Galia).

94 „Medium Salutis", S. A., vol. II, pars VI, 276 (USA).

95 S. A., vol. II, pars VI, 78-79 (Canada).

96 S. A., vol. II, pars II, 510 (Holandia).

97 S. A., vol. III, 163.

98 S. A., vol. IV, pars II/1, 381 (G. D'Ercole: Pontificia Universitas Lateranensis).

99 S. A., vol. II, pars VI, 435 (G. O. Brady: USA).

${ }_{100}$ S. A., vol. II, pars VI, 383 (J. F. Rummel: USA).

101 S. A., vol. II, pars VI, 109 (G. Cabana).

102 S. A., vol. IV, pars II/1, 344. 
ciołem i zbawieniem, jest większe lub mniejsze, w zależności od ich treści semantycznej. Kościół jako „sztandar”, „znak”, „droga” zbawienia, tylko zbawienie ukazuje, ale nie musi go jeszcze sprawiać. Gdy się natomiast mówi, że Kościół stanowi „rację”, „,́́rodek”, „narzędzie”, „źródło" zbawienia, jest „szafarzem” zbawienia, to widać od razu, że rola jego w tym względzie jest znacznie większa, zakłada jakąś formę skutecznego działania zbawczego ze strony Kościoła.

Wydaje się, że obojętnie który rodzaj skuteczności, każda z powyższych nazw, może posiadać i wyrażać, wszystkie akcentują bardzo mocno implikacje chrystologiczne i soteriologiczne eklezjologii. Kościół bowiem jest tym wszystkim dzięki swoim odniesieniom do Chrystusa i do człowieka zarazem. Skuteczność działania zbawczego zapewnia Kościołowi Chrystus. Działanie to $z$ kolei koncentruje się na człowieku: pragnie służyć człowiekowi i zbawiać człowieka. Tym samym określenia te odsłaniają mniej lub więcej wyraziście różne aspekty sakramentalnej struktury rzeczywistości eklezjalnej, to że Kościół jest sakramentem zbawienia, przy czym to ostatnie jest zbawieniem w sensie transcendentnym, a nie immanentnym, tzn. pełną swoją realizację znajduje we wspólnocie życia Bożego, częściowo osiągalną już tu na ziemi, a nie w rozwoju czysto doczesnym człowieka.

c) Pojęcie sakramentu w ścisłym znaczeniu słowa ma długą historię. Swój ostateczny i definitywny wyraz, obowiązujący dzisiaj w Kościele, zawdzięcza decyzjom doktrynalnym Soboru Trydenckiego. Według Tridentinum sakramentami są znaki widzialne sprawiające niewidzialną łaskę. Będąc symbolami rzeczy świętych i dostrzegalnym kształtem nadprzyrodzonego daru, swoją naturą i funkcją wykraczają jednakże poza ramy zwykłych symboli czy zewnętrznych sprawdzianów przyjętej wiary. Mocą ustanowienia Chrystusowego powodują to, co oznaczają. Pomiędzy sakramentalnym znakiem i zdziałaną przezeń Bożą łaską zachodzi przyczynowy związek. W tym znaczeniu istnieje - zdaniem Soboru Trydenckiego - tylko siedem sakramentów świętych ${ }^{103}$.

Zachodzi tutaj pytanie, czy wśród denominacji Kościoła występujących $\mathrm{w}$ dokumentacji przedprzygotowawczej Vaticanum II, znajduje się również nazwa sakrament i jeżeli tak, to w jakim stosunku pozostaje ona do co dopiero przytoczonej trydenckiej definicji sakramentu. Otóż, wydaje się, że na oba człony $w$ ten sposób sformułowanego pytania należy odpowiedzieć pozytywnie, czyli że Kościół jest wprost nazywany sakramentem i określenie to implikuje realizację tego pojęcia sakramentu w Kościele i przez Kościół.

103 Decretum de sacramentis, DS 1601; 1602, a zwłaszcza 1606; Decretum de ss. Eucharistia, DS 1639. - Por. I. Różycki, Podstawy sakramentologii, Kraków 1970, 50-102 (Rozwój pojęcia sakramentów w historii dogmatów). 
Oto trzy teksty, w których Kościół wyraźnie został nazwany sakramentem: — „Z Pisma Św. wynika, że Kościół jest także ziemską rzeczywistością widzialną, hierarchiczną, i jednocześnie sakramentem swego niewidzialnego misterium” (J. J. Weber, bp Strasburga) 104. — „Należy ponadto odnotować, że Kościół jest prasakramentem, skoro w nim są obecne słowa zbawienia i łaska Chrystusa" (J. kard. Doepfner, bp Berlina) ${ }^{105}$. - „Powinno się podkreślać dwa aspekty Kościoła, mianowicie, że jest społecznością zbawienia i wspólnotą świętych, która urzeczywistnia się dzięki uświęceniu człanków, zawsze należących do Boga. To urzeczywistnienie nie ogranicza się do ziemi, ale trwa na wieki, choć przekracza zdolność naszego pojmowania. Następnie Kościół jako społeczność hierarchiczna na tej ziemi, a przez to i doczesna, jest właściwym i najstosowniejszym środkiem do uświęcenia ludzi zgromadzonych w Kościele. A zatem jest świętym znakiem lub sakramentem, który oznacza i tworzy wspólnotę świętych" (A. Soegijapranata, wik. ap. Semarang - Indonezja) ${ }^{106}$.

Nadto wotum Fuldańskiej Konferencji Episkopatu mówi o ,strukturze chrystologicznej i sakramentalnej" (christologica et sacramentalis) Kościoła ${ }^{107}$, a Uniwersytet Katolicki w Nijmegen wymienia jego ,,charakter sakramentalny, czyli widzialnie ziemski" (sacramentalis seu visibiliter terrestris) ${ }^{108}$.

Bliższa analiza przytoczonych tekstów prowadzi do wniosku, że w ich ujęciu Kościół, mimo całej swojej nadrzędności i odrębności w odniesieniu do każdego z siedmiu sakramentów, rzeczywiście jest sakramentem, tzn. że jego natura i misja są ukształtowane na wzór sakramentalny, czyli znaku skutecznego łaski.

Według bpa J. J. Webera, Kościół w hierarchicznej, ziemskiej swojej rzeczywistości jest sakramentem, tzn. widzialnym znakiem swojego niewidzialnego misterium. To misterium zostało przezeń nieco dalej w wypowiedzi określone jako, ,życie Chrystusa przechawywane i wzrastające

104 S. A., vol. II, pars I, 415: „Ecclesia est etiam et simul terrestris realitas, visibilis, hierarchice, sacramentum sui invisibilis mysterii, sicut ex Scriptura apparet".

i05 S. A., vol. II, pars I, 584: „Insuper notetur, Ecclesiam esse <sacramentum originans $>$ (Ursakrament), cum in ea verba salutis et gratia Christi praesentia sint". $\mathrm{Na}$ tekst ten wskazał także L. Boff w Kirche als Sakrament, 231 p. 13 z tym, że w miejsce zwrotu ,sacramentum originans" ma „sacramentum originale”, co by wskazywało, że nie korzystał z oficjalnego tekstu $S$. A.

${ }_{106}$ S. A., vol. II, pars IV, 253-254: ,Ut emphasis detur duobus aspectibus Ecclesiae: scilicet ut societas salutis vel communio Sanctorum, cuius realitas consistit in sanctificatione membrorum, quae Deo semper adhaerent. Quae realitas non limitatur hac in terra sed in aeternum manet licet perceptionem nostram superat. Proin Ecclesia ut societas hierarchica hac in terra ideoque temporalis, quae est medium debitum et aptissimum ad sanctificandos homines in Ecclesia congregatos. Et igitur sanctum signum vel sacramentum, quod communionem Sanctorum significat et perficit".

${ }_{107}$ S. A., vol. II, pars I, 746.

108 S. A., vol. IV, pars II, 478. 
w Kościele i jego członkach zarówno na skutek przepowiadania Słowa Bożego jak i dzięki sakramentom, które są czynami Zbawiciela przez Kościół”. Również u kard. J. Doepfnera, Kościół staje się ,prasałra-mentem” (Ursakrament), podstawowym znakiem, przez „obecność w nim orędzia zbawienia i łaski Chrystusa”. Wreszcie bp S. Soegijapranata, opisawszy dwa aspekty Kościoła: ,,społeczność zbawienia lub wspólnotę świętych", utworzoną przez członków należących do Boga i przekraczającą wymiary czasu i przestrzeni, oraz ,doczesną społeczność hierarchiczną, stale pozostającą na ziemi”, stwierdza, że ta druga, stanowiąc „odpowiedni i najwłaściwszy środek do uświęcenia ludzi zgromadzonych w Kościele" jest „znakiem lub sakramentem”, ponieważ „oznacza i sprawia” pierwszą — ,wspólnotę świętych". Wszystkie trzy opinie widzą zatem element wewnętrzno-nadprzyrodzony i zewnętrzno-ludzki Kościoła w relacjach podobnych do tych, jakie zachodzą pomiędzy znakiem i łaską w sakramentach. W ich przekonaniu Kościół jako taki realizuje istotnie, choć nie tak samo jak w siedmiu sakramentach — analogicznie — definicję sakramentu.

Ta struktura sakramentalna Kościoła jest w gruncie rzeczy strukturą chrystologiczną. Jezus Chrystus, Bóg - człowiek, stanowi bowiem pierwowzór wszelkiej sakramentalności. W osobie Syna Bożego, cielesna, zmysłami dostrzegalna natura ludzka była znakiem, obecnej i działającej zbawczo, niewidzialnej boskiej natury. Jednakże sakramentalna struktura Kościoła nie utożsamia się bez reszty ze strukturą sakramentalną Chrystusa: wykazuje tylko równoległość i podobieństwo cech. Sakramentalność Chrystusa pozostaje bowiem zawsze czymś zupełnie odrębnym, czymś absolutnie niepowtarzalnym. Niemniej, będąc ukształtowana według tego modelu natura Kościoła, słusznie została nazwana przez wotum Fuldańskiej Konferencji Episkopatu strukturą chrystologiczną i sakramentalną. W rzeczy samej, oba te zwroty są określeniami wyrażającymi, każdy na swój sobie właściwy sposób, bosko-ludzki charakter rzeczywistości eklezjalnej. Stąd „,charakter sakramentalny Kościoła” jak zauważa słusznie Katolicki Uniwersytet w Nimegen - bynajmniej nie pomija, lecz wprost oznacza także jego „widzialno-doczesną stronę”.

d) W tym kontekście nie powinno dziwić domaganie się większego powiązania nauki o sakramentach z Chrystusem i Kościołem. W przekonaniu wielu głosów nie dość dotąd mówiło się, że ,w sakramentach działają zasługi i moc męki Chrystusowej" i że ta moc płynie z Chrystusa za pośrednictwem właśnie sakramentów Kościoła ${ }^{109}$. Swoją skuteczność,

109 „Magnopere desiderandum videtur, ut in doctrina de Sacramentis amplius illustretur declareturque ea cum Christo et cum Ecclesia arctissime cohaereri. Plerumque enim non satis docetur <meritum et virtutem passionis $>$ Christi <operari in Sacramentis" $>, S$. A., vol. IV, pars II, 243 (Universitas Catholica Lublinensis). 
którą niejako budują Kościół, mają one przecież od samego Słowa Wcielonego ${ }^{110}$. „Jako znaki sprawiające łaskę Bożą zapoczątkowują lub przywracają albo też pogłębiają nie tylko więzi witalne pomiędzy Bogiem i wiernymi, lecz także pomiędzy Kościołem i wiernymi" 111. Dzięki sakramentowi chrztu Kościół pomnaża ilość swoich dzieci. Eucharystia wzmacnia jedność Ciała Chrystusa. Przez inne sakramenty Kościół obwieszcza i wlewa w swoje członki życie i działanie Chrystusa ${ }^{112}$. Za wzorem człowieczeństwa przyjętego przez Słowo w roli narzędzia zjednoczonego (instrumentum coniunctum), by obdarować łaską zbawczą, sakramenty zostały ustanowione przez Chrystusa jako narzędzia rozdzielone (instrumenta separata) dla przekazywania tejże łaski poszczególnym duszom. Stąd układ sakramentalny stanowi jakby przewód życiodajny Mistycznego Ciała, w którym sakramentalność i społeczny charakter Kościoła są tak ze sobą powiązane, że zbawienie człowieka urzeczywistnia się za pomocą niższych stworzeń i wytwarza w Kościele jakby solidarność rodzinną ${ }^{113}$.

Wydaje się, że to, co powyżej zostało powiedziane na temat roli siedmiu sakramentów w Mistycznym Ciele Chrystusa, pozwala także bliżej określić ich wzajemne, bardzo bliskie związkı. Jako swoisty sakrament, Kościół po prostu urzeczywistnia się w siedmiu sakramentach. Inaczej mówiąc, sakramenty są tylko różnymi środkami, pozwalającymi Kościołowi na realizację dzieła zbawczego Chrystusa przez uświęcanie chrześcijan w ciągu całego ich życia. Wynika stąd, że sakramentalność Kościoła oznacza nie tyle sakramentalne działanie obok zbawczego działania siedmiu sakramentów, co podstawową, sakramentalną rzeczywistość zbawczą, która w siedmiu specjalnych sakramentalnych znakach aktualizuje swą własną sakramentalność. Tak więc eklezjologia dokumentacji przedprzygotowawczej stwierdzając sakramentalność Kościoła równocześnie widzi eklezjalny wymiar sakramentów.

\section{KONCOWE UWAGI.}

Najogólniej rzecz ujmując trzeba będzie w końcowym słowie stwierdzić, że proponowany przez dokumentację przedprzygotowawczą Vaticanum II eklezjologiczny traktat był już nie tylko traktatem apologetycz-

110 S. A., vol. II, pars I, 646 (L. Jaeger: Germania).

111 S. A., vol. II, pars III, 423 (C. Ursi: Italia).

112 S. A., vol. IV, pars II, 497 (Universitas Catholica Parisiensis: Facultas Theologica). - Por. także dane na temat sakramtntów św. zebrane przez Apendyks. S. A. Appendix Voluminis II, pars II: De Sacramentis - De Locis Sacris - De Praeceptis ecclesiasticis - De Cultu Divino - De Magisterio Ecclesiastico - De Beneficiis et de Bonis Ecclesiae Temporalibus - De Processibus - De Delictis et Poenis - De Missionibus - De Oecumenismo - De Auctositate Ecclesiae, TPV 1961, 3-188.

${ }_{113}$ S. A., vol. III, 12 (Suprema Sacra Congregatio Sancti Officii). 
nym, lecz także dogmatycznym. Postawienie aspektu dogmatycznego po apologetycznym w traktacie eklezjologicznym ma tutaj swoje uzasadnienie w zapleczu tekstowym. Zaplecze to ukazuje bowiem, w jakim stop-. niu poszczególne orientacje eklezjologiczne faktycznie współkontynuowały świadomość eklezjalną. Otóż trzeba obiektywnie przyznać, że pomimo istnienia naszkicowanej dogmatycznej koncepcji Kościoła, w badanej dokumentacji przeważają głosy postulujące rozpatrywanie klasycznych tematów związanych treściowo z eklezjologią instytucjonalną jak: ,autorytet i magisterium papieża”; „nieomylność papieska”; „opieka Boża nad nauczaniem papieskim”; ,powaga encyklik”; ,posłuszeństwo należne dokumentom papieskim”; „władza biskupia”; ,pochodzenie władzy biskupiej”; „,biskup jako pasterz diecezji”; ,stosunek władzy biskupiej do papieskiej”; , biskup i kapłani”; „magisterium Kościoła”; „,rozwój dogmatów”; „,nowe definicje dogmatyczne”; „znamiona Kościoła”; „,członkowie Kościoła”; „stosunek Kościoła powszechnego do partykularnego”, itp. ${ }^{114}$. Niewidzenie tego stanu rzeczy byłoby czymś jednostrannym, a więc i jakoś nie w pełni prawdziwym i to tym bardziej, że wprost temat sakramentalności został podjęty tylko przez nieliczne wypowiedzi.

Stwierdzenie to dowodzi, że asymilacja nowych form myślenia teologicznego powstałych na gruncie prowadzonych badań, dokonuje się w Kościele wolno, że nie zawsze natychmiast to, o czym mówią i piszą teologowie, stanowi automatycznie powszechne przekonanie pasterzy i wiernych. Teza o sakramentalności Kościoła, mimo różnic interpretacyjnych $\mathrm{w}$ okresie bezpośrednio poprzedzającym Vaticanum II, była bowiem powszechnie przyjętą $\mathrm{w}$ teologii ${ }^{115}$, zatem sytuacja panująca na tym odcinku $\mathrm{w}$ teologii $\mathrm{z}$ całą pewnością nie znalazła proporcjonalnego odzwierciedlenia w dokumentacji przedprzygotowawczej. Może w jeszcze większym stopniu opisane zjawisko dotyczyło eklezjologii biblijnej. Obrazy biblijne Kościoła, zwłaszcza Kościół jako Lud Boży, występują tam rzadko, a te które się pojawiają, są bardzo nieliczne ${ }^{116}$. Konsekwentnie, eklezjologia wypowiedzi operuje językiem i pojęciami teologii ukształtowanej przez scholastykę i neoscholastykę z przełomu XIX i XX w., którymi posługiwały się także w znacznej mierze enuncjacje papieskie i tzw. ,teologia szkolna” (Schultheologie).

114 Kompletny zestaw tych tematów w S. A., podaje Appendix Voluminis II, pars I, 43-68; $76-80$.

115 M. Bernards, Zur Lehre von der Kirche als Sakrament. Beobachtungen aus der Theologie des 19. und 20. Jahrhunderts, "Münchener Theologische Zeitschrift", 20 (1969) 29-54. - Z polskich autorów zob. A. Skowronek, Kościót jako prasakrament, „Ateneum kapłańskie”, 68 (1965) 1-10.

${ }_{116}$ "Np. „Sponsa Filii Dei”; „Sponsa Christi”; „Familia Dei Patris”; „Dei Regnum"; "Populus Dei", S. A. Appendix Voluminis II, pars I, 37; 78. - Por. R. Eukaszyk, Pojęcie Kościoła jako Ludu Bożego w eklezjologii Vaticanum II, „Roczniki Teologiczno-Kanoniczne", 16 (1969, z. 2) 41-62. 
W kwestii formuły stwierdzającej sakramentalność eklezjalną wydaje się, że dla nikogo nie ulegał wątpliwości, teandryzm eklezjologiczny taki, jakim go znała wcześniejsza tradycja teologiczna, od św. Pawła począwszy poprzez Ojców Kościoła i scholastykę, który to teandryzm z powrotem został ,odkryty” przez Szkołę w Tybindze i szkołę rzymską w XIX w., a swoją powszechną obecność w świadomości Kościoła pod postacią doktryny o Kościele Mistycznym Ciele Chrystusa, zawdzięczał przede wszystkim papieskiemu nauczaniu zwyczajnemu, zwłaszcza Leona XIII i Piusa XII 117. Natomiast nowa wersja tego teandryzmu eklezjalnego, mówiąca o Kościele jako powszechnym sakramencie zbawienia, mimo swej niewątpliwej ciągłości w tradycji i powszechnej obecności w refleksji teologicznejpodrugiejwojnieświatowej, niebędąc przeznikogo kwestionowana, była wszakże tylko znana, tzn. liczyła się jedynie jako teoretyczna możliwość, ale faktycznie nie współkształtowała jeszcze świadomości eklezjalnej Ludu Bożego. Odnosi się to zarówno do wyraźnych sformułowań sakramentalności Kościoła jak i jej wariantów równoznacznych czy równoważnych. Dane dostarczone przez nie nie wykraczają bowiem poza sygnalizację problemu.

Tam natomiast, gdzie zjawia się owo pogłębione ujęcie rzeczywistości elklezjalnej, bywa przedstawiane jako motyw jedności w Kościele i przez Kościół; jedności obejmującej zarówno związki człowieka z Bogiem jal i stosunki międzyludzkie. Kościół bowiem — zdaniem wielu wypowiedzi sam w sobie wzięty jest „miejscem wspólnoty Boga i ludzi w Chrystusie” ${ }^{118}$, „,znakiem i źródłem prawdziwej jedności” 119, ,jedynym, boskim wzorcem jedności rodzaju ludzkiego ${ }^{120}$, ponieważ w Kościele poszczególni wîerni osiągają , życie Boże i najściślejszą jedność z Chrystusem i między sobą" ${ }^{121}$. Ta wewnętrzna jedność ludzi w Chrystusie, czyniąca z nich jedno ciało, jest także rezultatem ich zewnętrznego związku z hierarchią 122. I trzeba tutaj stwierdzić, że ów motyw jedności w Kościele i przez Kościól, obojętnie gdzie i w jakiej formie się zjawia w dokumentacji przedprzygotowawczej, występuje zawsze jako element składawy natury i misji Kościoła; jest rzeczywistością, ale i zadaniem Kościoła kontynuującego dzieło

117 Por. Tyszkiewicz, Où en est chez nous la doctrine de la divino-humanité de l'Egise?, 369-405; C. Journet, Le caractère théandrique de l'Eglise, source de tension permanente, w: L'Eglise de Vatican II, (Unam Sanctam 51b), t. II, Paris 1966, $299-312$.

118 S. A., vol. II, pars I, 374 (A. Fauvel: Galia').

119 S. A., vol. II, pars III, 331 (B. L. Migliorini).

120 S. A., vol. II, pars VI, 342 (P. Schulte).

121 S. A., vol. II, pars III, 269 (A. Bagnoli: Italia').

122 S. A., vol. II, pars V, 67 (A. M. I. Durrieu). 
zbawcze Chrystusa dzięki ożywieniu przez Ducha Świętego. Ludzie współcześni dążący do zjednoczenia rodziny ludzkiej mają zatem w Kościele dzięki jego chrystologicznej i sakramentalnej strukturze olbrzymią szansę pełnej i najgłębszej realizacji swoich pragnień.

Przy tym wszystkim należy jeszcze zdawać sobie sprawę, co również po wielekroć zostało zauważone, że Kościół - Mistyczne Ciało Chrystusa nie jest czymś, co w swej wewnętrznej naturze dałoby się całkowicie rozpoznać ludzkim umysłem. Głębia misterium Kościoła może być zaakceptowana przez cziowleka tyıko na piaszczyznie wiary, jako część objawienia chrześcijańskiego ${ }^{123}$. Kościół zatem jest i musi pozostać nadal przedmiotem wiary ${ }^{124}$. Wierni powinni spoglądać nań nie tylko oczyma wiedzy historycznej czy socjologicznej, lecz także w świetle wiary i z dziecięcą miłością ${ }^{125}$.

Przypomnienie tych założeń gnoselogicznych względem Kościoła przez dokumentację przedprzygotowawczą Vaticanum II, stanowi także ważkie świadectwo nowego podejścia do jego rzeczywistości. Katolicki traktat eklezjologiczny okresu potrydenckiego mając głównie charakter apologetyczny, tzn. przydzielając pierwszeństwo polemice i metodzie dowodzenia, faworyzował racjonalne rozpatrywanie tematu Kościoła. Zgłębianie samej treści misterium eklezjalnego siłą rzeczy schodziło wtedy na dalszy plan, choć nie można powiedzieć, żeby w ogóle go nie było. Przy tej orientacji wiara jako narzędzie poznawcze Kościoła miała po prostu mniejsze znaczenie. Że jednak z jej nieodzownością w tym względzie i wtedy się liczono, świadezy wymownie włączanie Kościoła, przez Suwor Trydencki także ${ }^{126}$, do wyznania wiary. Zaakcentowanie wiary w procesie poznania Kościoła nie negując bynajmniej, że w Kościele są rzeczy i sprawy dostrzegalne oczyma, badane i kierowane rozumem, chciało tutaj powiedzieć, że jego najgłębszą, wewnętrzną i nadprzyrodzoną rzeczywistość udostępnia człowiekowi jedynie wiara.

Rzecz zrozumiała, że powyższa zasada poznawcza odnosi się także do sakramentalnej struktury Kościoła. Kategorie wyrażające sakramentalność stanowią, mimo wszystkich swoich relacji do świata rzeczy i ludzi, istotny element objawienia chrześcijańskiego. Z tego względu i sakramentalność eklezjalna tylko z pomocą wiary może być poprawnie odczytana i przedstawiona.

123 S. A., vol. IV, pars II, 620 (Universitas Catholica Americanae Washingtonensis). - Por. także $S$. A., vol. II, pars I, 643 (L. Jaeger').

124 S. A., vol. IV , pars II, 183 (Universitas Catholica Insulensis).

125 S. A., vol. II, pars I, 405 (P. Douillard).

126 DS $1500 ; 1862-1870$. 


\section{L'EGLISE - SACRAMENT \\ DANS LA DOCUMENTATION ANTÉPREPARATOIRE DU VATICAN II \\ R E S U M E}

Après avoir annoncé la convocation de Vatican II, le pape Jean XXIII a institué une commission antépréparatoire de ce concile. Cette commission a alors envoyé, au début de l'été 1959, trois textes aux évêques et aux prélats, aux Congrégations de la Curie de Rome, ainsi qu'aux universités ecclésiastiques et aux facultés catholiques. Les réponses constituent la Série antépréparatoire des sources aux études de Vatican II. C'est, jusqu'à maintenant, le sondage le plus complet et le plus représentatif des opinions de l'Eglise.

Dans ces matériaux, l'auteur s'est donné la tâche de trouver l'une des formules ecclésiologiques, à savoir celle qui définit l'Eglise comme un Sacrament. Il attire d'abord l'attenton sur le postulat, communément rencontré, de la vision plénière et approfondie de l'Eglise unique, visible et invisible, hiérarchique et juridique et en même temps charismatique et mystique, en un mot que soit rejeté le dualisme qui opose l'Eglise juridique à l'Eglise d'amour, car ce ne sont là que deux aspects différents de la seule et même Eglise. Or, celle-ci est une communauté parfaite animée par l'Esprit Saint, et qui, bien qu'existant sur terre, n'atteindra à sa pleine réalisation qu'après avoir tout accompli dans le Christ. Ces propriétés sont le plus souvent désignées sous le nom de „Corps Mystique du Christ”, ce qui, dans la documentation, est synonyme du mot „Eglise”. On a ensuite montré l'aspect christologique et pneumatologique de la réalité ecclésiale, fortement souligné dans de nombreuses réponses. L'Eglise est théandrique, semblable au Christ du fait que, en dehors du côté visible, elle a l'Esprit Saint à l'aide duquel elle réalise la consécration du monde, commencée dès la venue de son Chef - le Christ.

Ce qui apparaît aussi dans cette documentation, c'est la nette conscience de la structure sacramentelle de l'Eglise. Toutefois, les formes d'expression sont très diversifiées, selon la manière dont la conception de sacrement y est impliquée, largement ou étroitement. Ainsi, les réponses analysées parlent de l'Eglise comme Sacrement au sens de „mystérion” néotestamentaire traduit en latin par „mysterium" (plus souvent), ou par „sacramentum" (plus rarement), donc au sens de mystère de l'action salvifique de Dieu parmi les hommes dans le monde. On trouve aussi la conception du sacrement comme aide salvatrice en général. On en voit la preuve dans les dénominations de l'Eglise telles que „signe”, „voie”, „raison”, „moyen”, „instrument”, „source” de salut et autres semblables. Enfin, l'Eglise a été quelques fois tout simplement nommée ,sacrement”, comme signe visible assurant, grâce au Christ, la participation à une vie en commun avec Dieu. Dans ce contexte il ne faut alors pas s'étonner que les textes exigent une plus grande liaison entre la sacramentologie d'une part, la christologie et l'ecclésiologie d'autre part. L'Eglise vue ainsi ne peut être entièrement connue et approfondie qu'à l'aide de la foi.

Pour conclure, l'auteur remarque que le théandrisme ecclésiologique tel que le connaissaient st Paul, les Pères de l'Eglise et la scolastique, n'était mis en doute par aucun de ceux qui ont répondu. Ce théandrisme, redécouvert au XIX-e s. par l'école de Tübingen et celle de Rome, était universellement connu avant tout grâce au magistère ordinaire des papes. Cependant, sa nauvelle version, sous forme d'enseignement sur le caractère sacramentel de l'Eglise, malgré sa continuité dans la tradition théologique et sa universelle présence dans la réflexion théologique après la II-e guerre mondiale, bien que nullement contestée en principe, n'était que simplement connue. Elle ne façonnait pas, toute fois, la conscience ecclésiale du Peuple de Dieu. La justesse de cette affirmation se trouve confirmée par le petit nombre d'énoncés à ce sujet dans là documentation étudiée. 